\title{
Current Sustainable Trends of Using Waste Materials in Concrete-A Decade Review
}

\author{
Malindu Sandanayake *(D), Yanni Bouras, Robert Haigh ${ }^{\mathbb{D}}$ and Zora Vrcelj $\mathbb{D}$ \\ ISILC, College of Engineering and Science, Victoria University, Melbourne VIC3011, Australia; \\ yanni.bouras@vu.edu.au (Y.B.); robert.haigh@live.vu.edu.au (R.H.); Zora.Vrcelj@vu.edu.au (Z.V.) \\ * Correspondence: malindu.sandanayake@vu.edu.au; Tel.: +61-399195746
}

Received: 27 October 2020; Accepted: 15 November 2020; Published: 18 November 2020

\begin{abstract}
Concrete is the most used construction material in the world. Consequently, the mass extraction of virgin materials required for concrete production causes major environmental impacts. With a focus on promoting sustainability, numerous research studies on incorporating waste materials to replace virgin substances in concrete were undertaken. Despite this vast volume of published literature, systematic research studies on these sustainable concrete mixes that inform various stakeholders on current research trends, future research directions, and marketability options products are seldom conducted. This paper presents a decade review on sustainable concrete with a focus on virgin materials being replaced with waste materials. It aims to inform researchers of current research trends and gaps in the research area of waste material use in concrete. The review also identifies key parameters that restrict the marketability of these sustainable concrete products. The three-step research methodology involves a bibliometric assessment, a key review of selected waste materials, and an interview with a panel of experts focusing on impediments towards the transition of sustainable concrete products into the industry market. Bibliometric assessment was based on 1465 research publications in which five key materials (plastic, glass, fly ash, slag) and construction and demolition waste were selected for the review. The interview was conducted with ten industry experts to discuss the industry limitations in the commercial establishment of materials. The review of existing knowledge and the findings on sustainable concrete presented in this paper provide directions for both research academics and industry stakeholders to systematically focus on sustainable concrete products that are market-ready.
\end{abstract}

Keywords: concrete; construction; sustainable; materials waste

\section{Introduction}

With the exponential growth in population, countries across the globe are faced with continual growth of different kinds of waste. Developed countries like Australia generated around 67 million tons of waste in 2016/17 and only 37 million tons (55\%) were recycled [1]. On the contrary, it is reported that one of the biggest cities in China, Beijing, is mixing 25,000 tons of rubbish a day [2]. These waste materials are mainly sourced from household waste, commercial and industrial waste, and building and demolition waste [3]. Despite the possibility of reusing these waste materials, the majority are sent out to landfill, which not only negatively impacts the environment, but also causes social and economic implications. Efficient management, disposal, and reuse are key to addressing the governing issue of waste generation. Even though several strategies have been implemented to effectively manage, reuse, or dispose of waste, a contemporary solution which can close the loop and promote circular economy has not yet been achieved. The construction industry is one of the foremost contributors to environmental impacts and a substantial resource consumer. Throughout the entire life cycle, starting from material acquisition to their end-of-life, a built structure is responsible for significant 
energy consumption and carbon emissions [4-8]. A large share of this is due to the consumption of virgin materials during construction. Studies have shown that more than $15 \%$ of a building's energy consumption and carbon emissions are from materials [9-16]. In addition, use of excessive virgin materials in building materials results in natural resource usage and leads to additional environmental burden [16-18]. Therefore, replacing virgin materials with waste products addresses both key issues, excessive waste generation and virgin material usage.

Several research studies have focused on using waste products to manufacture various construction materials [19-24]. Undoubtedly, concrete has been regarded as the main building construction material which uses the majority of virgin materials and is responsible for significant energy consumption [25]. Over the past decade, numerous studies were concentrated on reducing energy and carbon footprint and diverting from virgin material use in concrete [21,26-29]. The primary motive of majority of these studies is to minimize the environmental impacts by replacing virgin materials with waste materials [19,30-33]. Therefore, using waste in construction materials such as concrete as a sustainable material that can facilitate environmental benefits was extensively researched. However, prior to labeling these as sustainable materials, several other factors such as social benefits, practical implementation, suitability, and availability need to be carefully benchmarked [16]. The main purpose for previous studies to use waste materials in concrete was to replace cement and thereby reduce virgin material usage [34,35]. Moreover, this also addresses the issue of the generation of huge waste amounts in landfills. However, the issue of using waste materials in concrete is highlighted in many studies in terms of high cost and energy consumption associated with processing the waste materials to a useable material [36]. Despite extensive research studies on various aspects of using waste products in construction materials, a systematic review of the existing body of knowledge is still absent, especially in the case of sustainable considerations of concrete manufactured from waste materials. Such a systematic investigation would not only identify the current research gaps but is also likely to emphasize the future research directions and trends. The current review study aims to investigate the current trends in using waste products in concrete and recommends the future research scopes. The outcomes of this paper provide useful findings and future directions for both industry and academic stakeholders interested in promotion of sustainable concrete.

\section{Research Significance and Methodologies}

Numerous waste products have been used in manufacturing concrete across the globe [25]. However, using a waste product in building material is often restricted due to factors such as material availability and cost issues. Besides, systematic reviews that can enable practitioners to better understand current practices, limitations and barriers, and future possibilities of benchmarking sustainability aspects of green concrete are seldom undertaken. The outcomes of the review will enhance understanding of the current trends and priorities for different waste products to be used as sustainable concrete. Various stakeholders will also be provided with the opportunity to understand the factors that need to be considered when selecting the most suitable waste products for the development of sustainable building materials. Endless types of waste materials can be used to develop sustainable concrete. These waste materials are selected based on the objective of the study and material availability $[16,30]$. Therefore, this research study initially focused on identifying the current trends in using waste products in concrete manufacturing by conducting a bibliometric assessment. A bibliometric assessment is a statistical approach that can facilitate the interconnections of previously published articles to critically analyze current trends and knowledge gaps [37]. The publications were selected from the Web of Science (WoS) search engine by using search criteria "sustainable concrete" "waste*", and the time period from 2009 to 2019. WoS was selected as one of the most comprehensive databases and easily adoptable in a bibliometric assessment software [38,39]. The search included journal articles, conference publications, books, and book chapters dealing with sustainable concrete that incorporates waste materials. The bibliometric assessment was undertaken by using a bibliography assessment software called Bibliometrix [40]. The research methodology including key steps in the 
bibliometric assessment is illustrated in Figure 1. Based on the findings and observations, a detailed review was undertaken on five selected major waste types used to manufacture concrete. These five waste materials were selected due to the heavy considerations of research studies concrete materials with waste. The review represents a thorough investigation on sustainable aspects of using key waste materials to manufacture sustainable concrete. Based on the review observations, ten experts in the field were consulted using stratified sampling to further understand the current impediments associated with commercial implementation of sustainable concrete. These findings will inform key researchers and readers on the limitations and barriers of the commercialization of sustainable concrete. Key findings would also enable the researchers to focus on transitional research on producing market-ready products by addressing the current impediments.

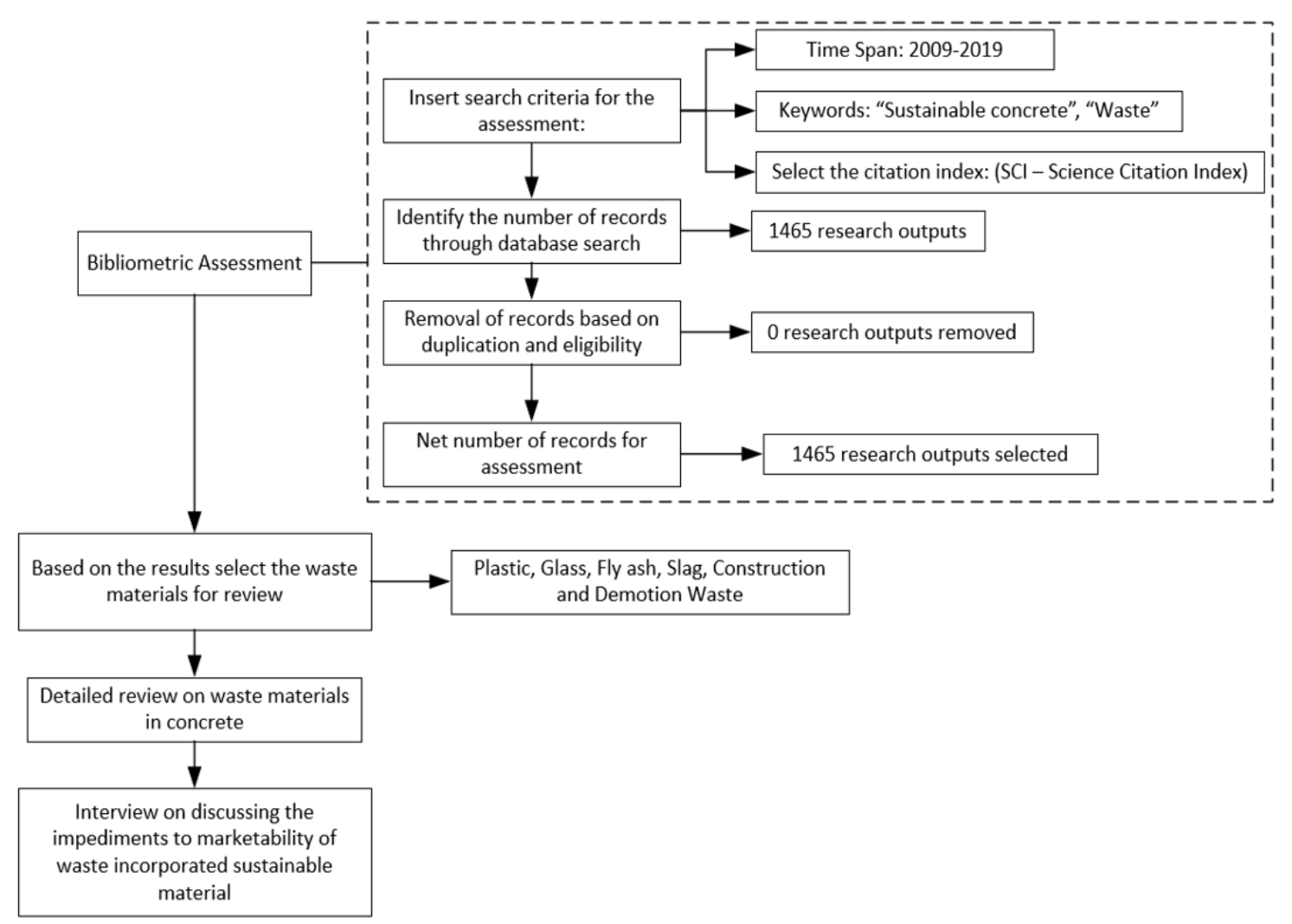

Figure 1. Research methodology process.

\section{Bibliometric Analysis Findings}

The main information obtained from the bibliometric analysis is highlighted in Table 1. A total of 1465 documents were sourced from 544 journals, books, conference papers, and proceedings. The analysis featured 4070 authors and 5593 author appearances. These figures provide an understanding on the author and co-author distribution with respect to scientific articles on waste materials in concrete. The "authors per document" (2.78) parameter indicated that at an average, one article is authored by three authors. "Co-authors per document" was calculated by the ratio between author appearances and documents. "Collaboration index" is an indicative term that calculated the number of authors in a multi-authored article per multi-authored article published. This provides a good indication of the level of collaboration for each published article.

The observations in Figure 2 show that in 2013, one or more published articles had the highest average total citations per year. In general, from 2013 onwards there were consistent average article citations, between three and four. 
Table 1. Main information from the bibliometric analysis.

\begin{tabular}{lc}
\hline \multicolumn{1}{c}{ Description } & Results \\
\hline Documents & 1465 \\
Sources (Journals, Books, etc.) & 544 \\
Keywords Plus (ID) & 1925 \\
Authors' Keywords (DE) & 3378 \\
Period & $2009-2020$ \\
Average citations per document & 11 \\
Authors & 4070 \\
Author appearances & 5593 \\
Authors of single-authored documents & 94 \\
Authors of multi-authored documents & 3976 \\
Single-authored documents & 101 \\
Documents per author & 0.36 \\
Authors per document & 2.78 \\
Co-authors per document & 3.82 \\
Collaboration index & 2.91 \\
Document types & \\
Journal articles & 1004 \\
Book chapters & 21 \\
Conference proceedings (book) & 10 \\
Conference proceeding paper & 314 \\
\hline
\end{tabular}

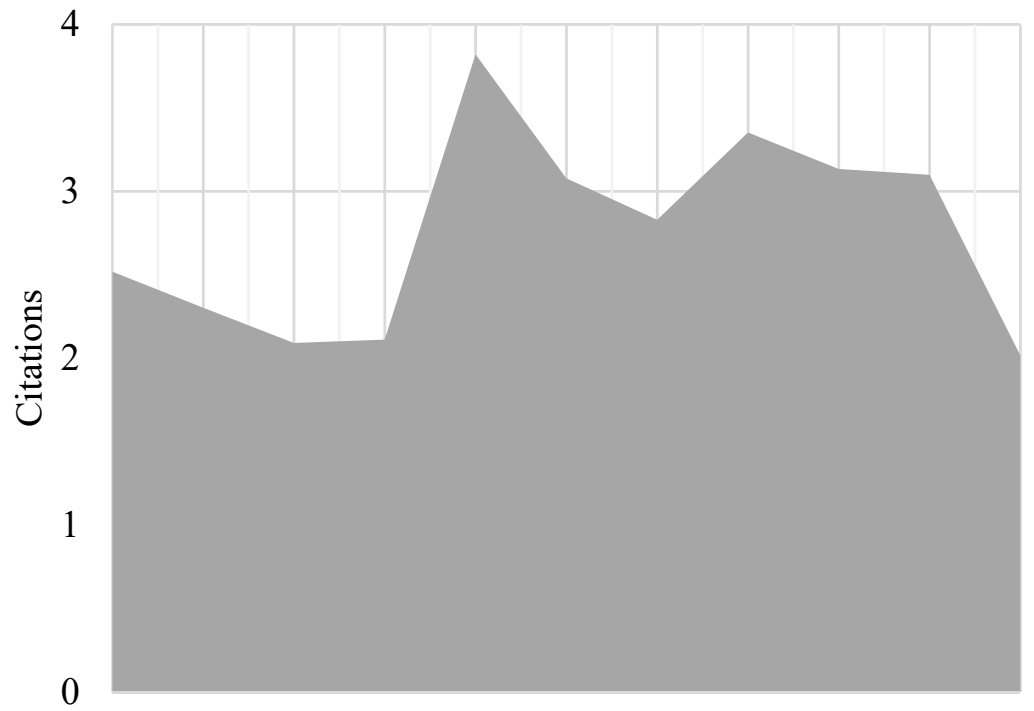

20092010201120122013201420152016201720182019

Figure 2. Average article citations per year.

On the contrary, annual scientific article publications per year, shown in Figure 3 highlighted an exponential growth, with a significant rise in number publications from 2017 to 2018. Noticeable increase was also observed in the number of publications from 2014 onwards.

Figure 4 illustrates the most cited countries and the most published journals within the sample collection. As observed, Journal of Construction and Building Materials and Journal of Cleaner Production are the governing publication sources. The high number of publications in these journals further justifies the higher focus on experimental studies investigating mechanical properties as compared to other sustainability criteria such as cost implications, local availability concerns, compliance considerations, and social impacts. 


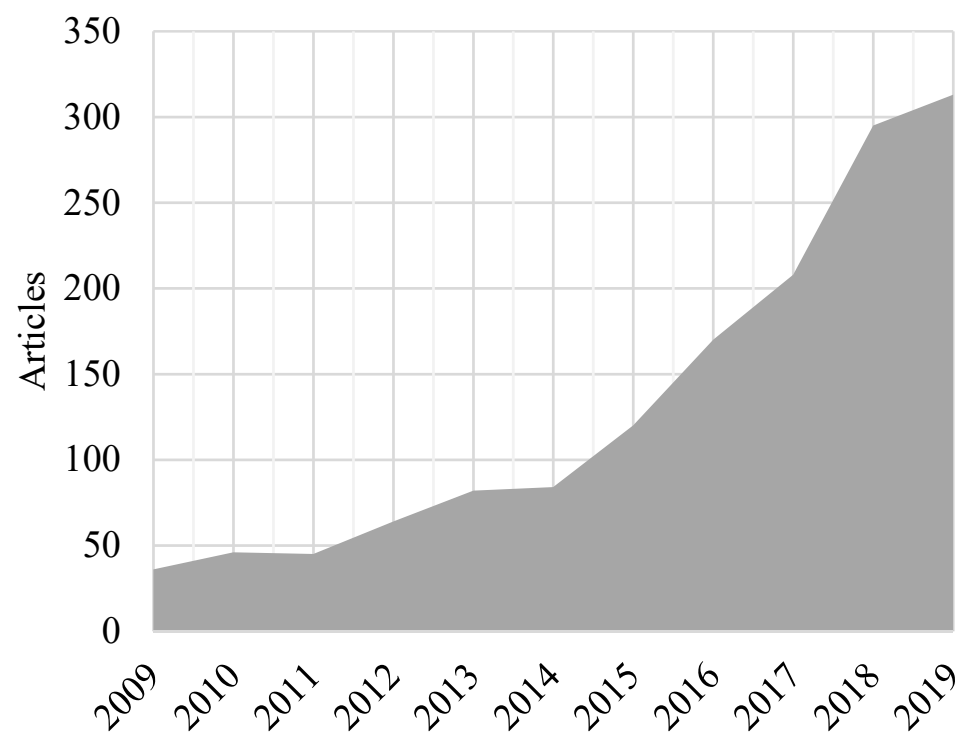

Figure 3. Annual scientific publications on sustainable concrete.
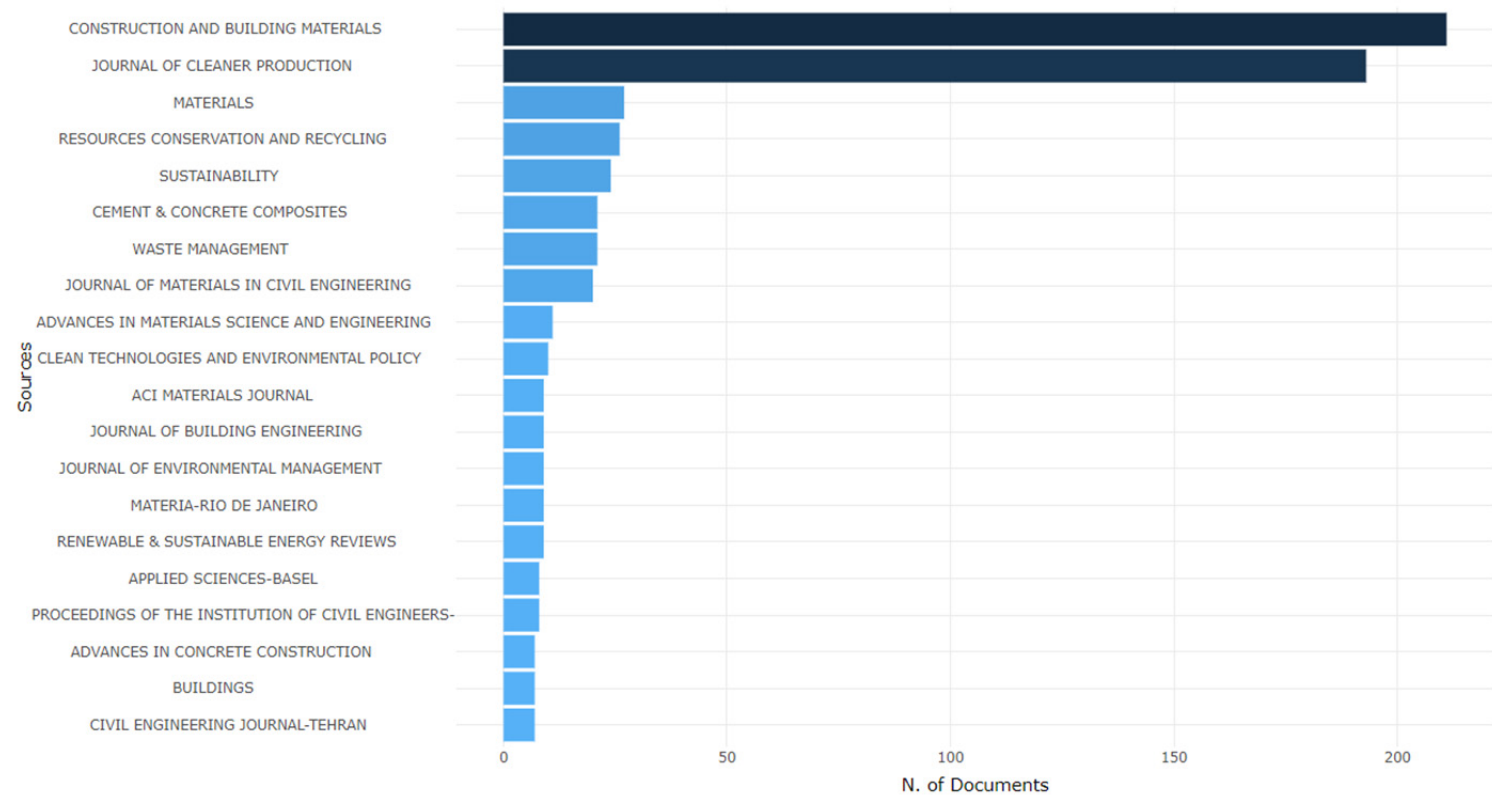

Figure 4. Publishing source vs. number of publications.

Three-plot Sankey plots, presented in Figures 5 and 6 highlight the key relationship between research focuses in the analyzed publication sample on sustainable concrete over the last decade. The thickness of the line between two entities depicts the strength of the relationship between the two variables. The relationship between "top authors", "keywords", and "publication source" is shown in Figure 6. "Top authors" in the figure refers to the first author in publication. The results indicate that Journal of Cleaner Production and Journal of Construction and Building Materials have extensively published research articles on the topics related to material properties and mechanical characteristics such as compressive strength, microstructure, and durability. Moreover, keyword relationship indicates that areas such as sustainability, life-cycle assessment, sustainable construction, waste management, and recycled materials were significantly present in previous studies. These observations exemplify that in addition to material and mechanical properties, environmental sustainability criteria were also 
researched significantly over the past decade. However, other considerations such as cost and local availability were seldom considered as the key focuses in these studies.

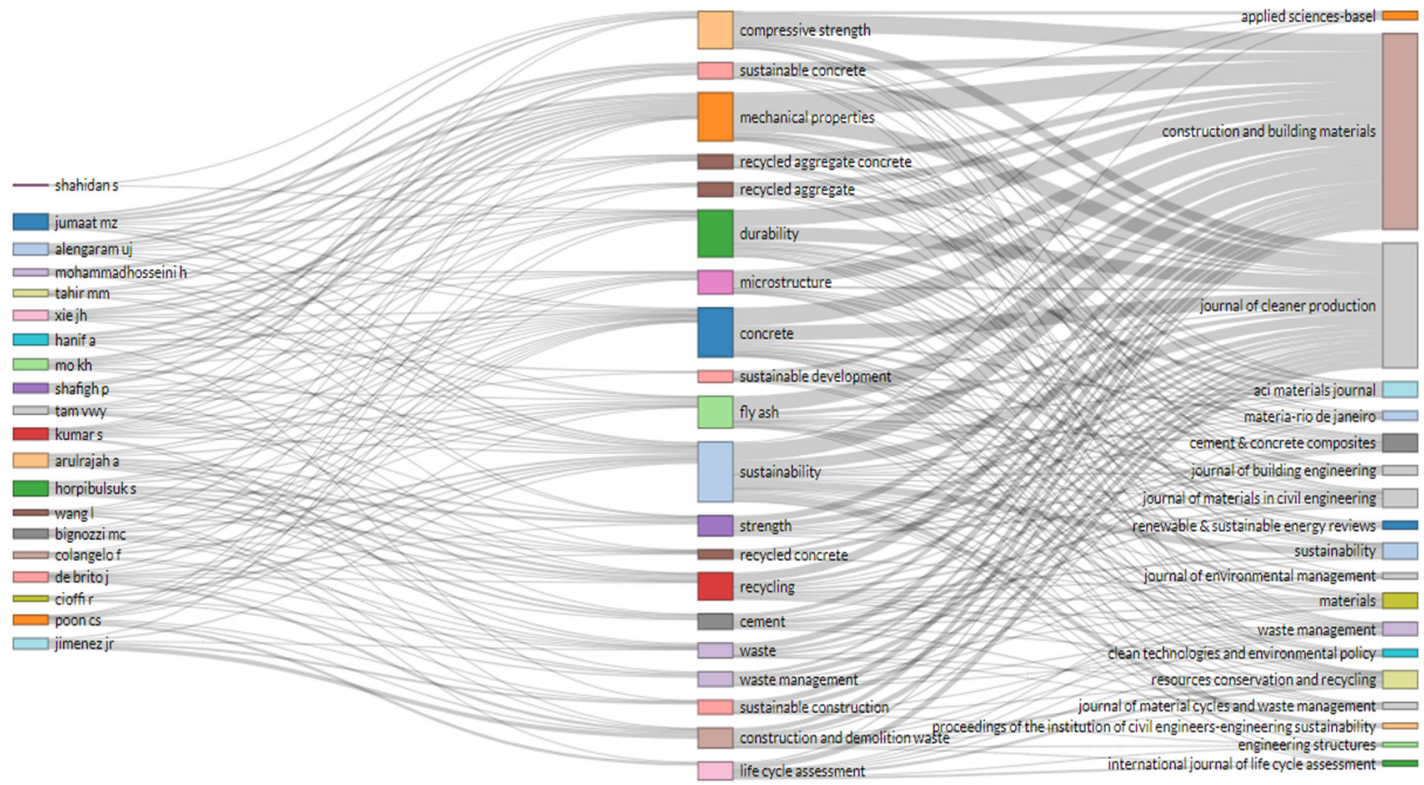

Figure 5. Three-plot between top authors vs. keywords vs. publications source.

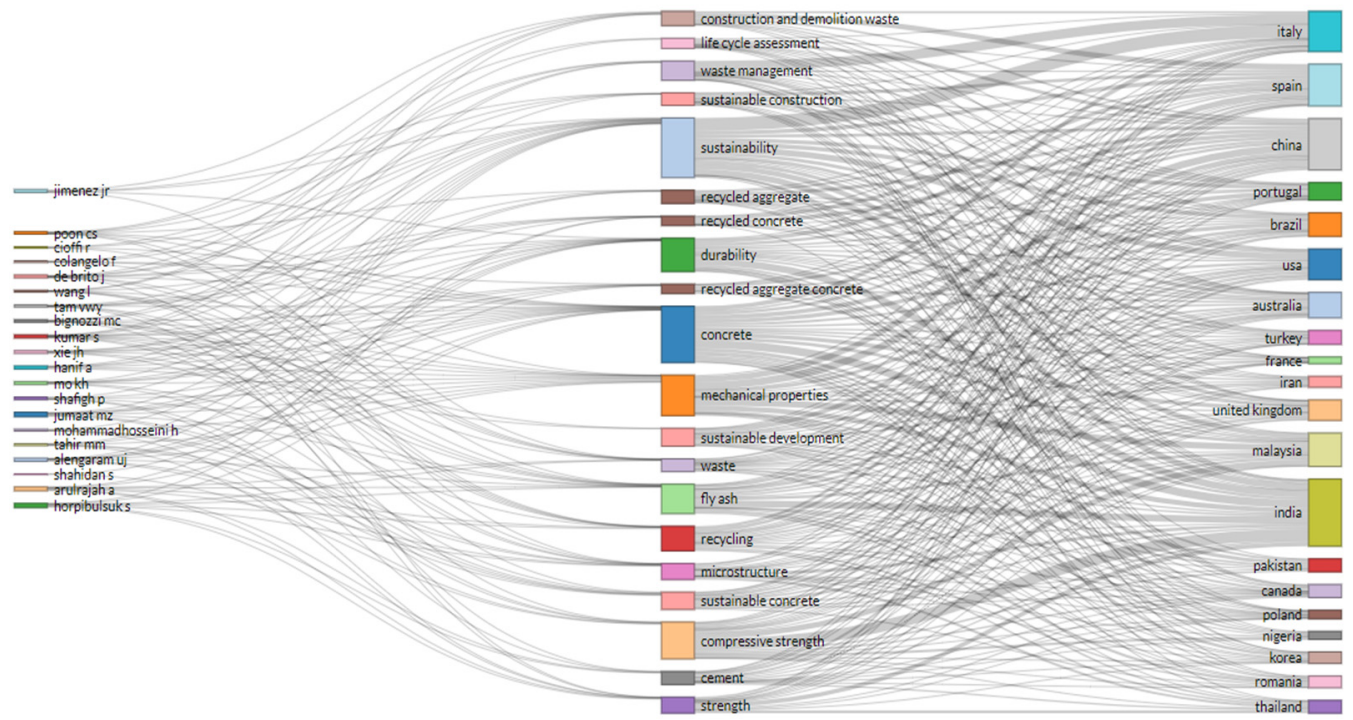

Figure 6. Three-plot between top authors vs. research focus vs. country.

The relationship between "top authors", "keywords", and "publication source" demonstrates research focuses of articles published in countries with most focus on waste materials in concrete. Asian countries, such as China and India, were focused heavily on fly ash concrete and recycled aggregate as materials, and compressive strength and durability as material characteristics. This could be due to the abundant availability of such waste materials in those countries. On the other hand, European countries, such as Italy and Spain, were mainly focused in their research on the sustainability waste management aspects of materials. The other dominant countries, such as Malaysia and the USA, included in the shortlisted publications sample seemed to uniformly focus on both sustainability and material properties in their published research articles. 
Summary of Findings

The bibliometric assessment revealed the following key findings and observations.

- Fly ash and recycled aggregate used in concrete production are the two major extensively researched waste materials;

- Use of waste materials in concrete as cement replacement and aggregate replacement are the major research focus of the sample;

- Only a handful of studies considered environmental benefits by using life cycle assessment to benchmark environmental sustainability benefits;

- Other sustainable benefits including economic benefits, social impacts, and other sustainable criterion were seldom considered in the available publications;

- Mechanical properties (mainly compressive strength) in waste-incorporated concrete were mostly researched in Asian countries while European countries (Italy, USA, and United Kingdom) focused more on waste management and sustainable development of these materials;

- Journal of Construction and Building Materials and Journal of Cleaner Production are the two prominent journals with research publications related to concrete with waste materials;

The bibliometric assessment findings have enabled readers to identify the key research focus areas, research trends, and provide guidance to future researchers on identifying influential journals, countries, and research focus areas on sustainable concrete. Based on the findings it was observed that cement replacement and use of recycled aggregate have been the two major focuses of previous studies in developing sustainable concrete. Therefore, the following review conducts an in-depth review on plastic, glass, fly ash, and slag as cement and virgin fine aggregate replacement materials and construction and demolition waste as a recycled coarse aggregate replacement material with a focus on sustainability aspects.

\section{Plastic Waste in Concrete and Mortar}

Extensive research efforts were made towards experimentally investigating the behavior of concrete and mortar containing recycled plastic waste products. The majority of these studies incorporated plastic as an aggregate substitute (plastic aggregates, PAs) or as fiber reinforcement (plastic fibers, $\mathrm{PFs}$ ), and many review papers were published on this subject [41-46]. More recently, Li et al. [47] conducted a review on the impacts of plastic and rubber aggregates on the physical, mechanical, durability, and functional properties of concrete. Faraj et al. [48] presented the state-of-the-art on the fresh and hardened properties of self-compacting concrete containing PAs and PFs. This paper reviews research on the use of plastic waste as an ingredient in concrete and mortars published from 2010-2019. Plastic waste used as aggregates and fibers are first discussed. Subsequently, research conducted on the use of plastic waste as a cement replacement and various other applications are reviewed. In addition to highlighting key research trends, the pertinent effects of recycled plastic on the environmental, durability, and thermal properties of concrete and mortars are reported.

\subsection{Plastic Aggregates and Fibers}

Table 2 lists the reviewed experimental research outputs dealing with the use of plastic waste as aggregate replacement in concrete and mortar. In addition, it presents the plastic types and quantities incorporated into the mixes, the sources of the waste, and processing methodologies adopted. Out of the 40 studies analyzed, 23 considered the use of polyethylene terephthalate (PET), typically recycled from plastic bottles. This is due to the large consumption and consequent availability, cost effectiveness, and simple recycling techniques of PET when compared with other plastics. The second most researched plastic type was polyvinyl chloride (PVC), with a total of four investigations. All other plastic types were considered three or fewer times. The origins of the plastic waste were mostly from drinking bottles and various industrial wastes. Recycling techniques employed were either mechanical 
shredding or industrial extrusion. Out of the papers reviewed, Italy and Portugal produced the most research, with six publications each. China generated four works, with all other countries yielding three or fewer studies.

This review identified 54 research outputs on the experimental investigation of recycled plastic fiber reinforced concrete published between 2010 and 2020. Out of these studies, 27 considered PET fibers mostly derived from used drinking bottles and 19 recycled polypropylene (PP) obtained from food-packaging, carpet production, and various other industrial wastes. Only three research works analyzed PVC fibers which were recycled from electrical cables and other industrial waste. Low-density polyethylene (LDPE) and high-density polyethylene (HDPE) were utilized in five and three investigations, respectively. Recycling of these plastics typically involved industrial extrusion or chemical and heating pre-treatment, whereas most other studies washed and manually or mechanically shred the waste. Two studies were conducted on each of the following: Polyethylene (PE) fibers, nylon fibers, and unspecified plastic type. India, Malaysia, and Italy produced the most research in this space with 11, 9, and 7 publications, respectively. Following was China and Iraq with three papers each. Studies from all other nations were two or fewer.

\subsection{Other Applications of Plastic in Concrete}

Few research efforts were made to investigate recycled plastics as ordinary Portland cement (OPC) replacement, especially when compared to substitution of aggregates or fiber reinforcement. Despite the potential to significantly reduce the embodied energy of concrete and mortar, this review identified only six research outputs on the subject published since 2009 [49-54]. This is likely due to the non-cementitious nature of plastic particles which, when mixed with cement paste, have adverse effects on mechanical behavior and compressive strength $[49,50]$. However, some of the strength loss can be compensated by irradiating the recycled plastic and combining it with Supplementary Cementitious Materials (SCMS), which reduce porosity and densify the cementitious matrix [51]. Mahdi et al. [52,53] developed Polymer Mortar (PM) and Polymer Concrete (PC) using recycled PET waste to produce the binding agent. This was achieved through glycolysis to depolymerize to PET, resulting in unsaturated polyester resin. The compressive strengths of the PM and PC ranged from 15 to $28 \mathrm{MPa}$ and from 20 to $42 \mathrm{MPa}$, respectively.

Three additional applications of recycled waste plastics in concrete structures were identified in the literature. Foti and Paparella [55] investigated the dynamic behavior of concrete reinforced with waste PET plastic. Long discrete PFs were obtained from manually cutting post-consumer drinking bottles and were arranged in a grid structure to reinforce concrete plates. Improvements to ductility and impact strength were observed in the PET-grid reinforced plates, suggesting potential applications in structures subjected to shock loading. Bending tests were performed on structural concrete reinforced with PET bars in place of traditional steel by Foti [56]. The benefits of such an application include milting crack development and corrosion resistance, though the strength of the PET-reinforced concrete was compromised possibly due to low adherence of the PET bars to concrete. Dai et al. [57] investigated the behavior of concrete confined by fiber-reinforced polymer (FRP) jackets formed with polyethylene naphthalate (PEN) and PET fibers derived from post-consumer bottles. The waste plastic FRPs significantly enhanced the ductility and slightly improved compressive strength, albeit to a much lesser extent than other FRPs.

\subsection{Sustainability Aspects of Using Plastic Waste in Concrete}

\subsubsection{Environmental Performance of Using Plastic Waste}

Few studies exist in the open literature which assess the environmental performance of concrete and mortars containing waste plastics. A cradle-to-gate Life Cycle Assessment (LCA) was conducted for concrete footpaths containing four different types of reinforcement by Yin et al. [58]. The types of reinforcement considered were traditional steel mesh, virgin PP fiber, industrial PP waste, and domestic 
PP waste. Recycling industrial and domestic PP waste resulted in significant environmental benefits when compared to the virgin PP fibers and traditional steel mesh options in terms of emissions and material consumption. When comparing industrial recycled PP fiber and steel mesh, carbon emissions, equivalent oil consumption, and water usage decreased by $93 \%, 91 \%$, and $99 \%$, respectively. However, the washing process required for recycling domestic PP waste increased water usage when compared to production of virgin PP fibers. Bhogayata and Arora [59] experimentally investigated the mechanical and physical properties of geopolymer concrete reinforced with Metalized Plastic Waste (MPW) fibers. Additionally, the environmental performance of the novel mixture was discussed by illustrating the life cycle of the waste product. It was postulated that the low resources required to shred and wash the waste for incorporation into geopolymer concrete could be a sustainable alternative due to pollution concerns relating to disposal and incineration.

\subsubsection{Durability Properties and Thermal/Fire Performance}

The addition of PAs and PFs was reported to significantly increase the water absorption and initial rate of absorption (IRA) of concrete [60-66]. This is attributed to the increased porosity, poor bonding between cement paste and Pas, and the increasing presence of cracking with increasing plastic content. Conversely, studies showed that the reductions in this property were caused by negligible permeability of PAs [67-70]. Drying shrinkage of concrete was generally found to decrease when substituting NAs aggregates with PAs $[27,62,70,71]$. This is a consequence of the hydrophobic nature of PAs which do not absorb water, therefore leaving additional free water for cement hydration. Though the results of Silva et al. [62] showed that increasing the quantity of plastic does not always lead to further reductions in drying shrinkage, conversely, drying shrinkage in concrete containing PET particles was measured in $[66,72,73]$ and an increasing drying shrinkage with fine aggregate replacement was observed. This is a result of NAs restricting shrinkage in cement and possibly due to a deteriorating elastic modulus [72]. Free drying shrinkage increases when reinforcing concrete with PFs, owing to the increase in pore volume and modifications to pore distribution $[65,74,75]$, though increasing the volume fraction does not always further increase the free drying shrinkage and some authors reported less drying shrinkage in PFR concrete [76-78].

Chemical resistance of plastic concrete was measured by Galvão et al. [79] through SEM analysis of samples artificially aged in a humid sulfur-dioxide containing chamber. Plastic concretes showed superior performance when compared to rubber concrete in relation to damaging crystal formation of sulfur-containing chemical phases. Concrete containing PBW aggregates was shown by Ghernouti and Rabehi [71] to feature improved chemical resistance to chloride ions and sulfuric acid solutions when comparted to normal concrete. Additionally, Ge et al. [67] found that plastic mortars containing PET aggregates were highly resistant to chemical attack as no reductions to compressive strength were observed after 30 cycles of wetting and drying in a sulphate solution. Coppola et al. [80] reported improved sulfate resistance in lightweight mortars when incorporating PAs due to the increase in macropores. Although chemical resistance was shown to reduce at higher replacement ratios, conversely, Silva et al. [62] reported a deterioration in chemical related durability properties of concrete when incorporating PAs. Chloride ion penetration and carbonation depths noticeably increased when incorporating PAs and generally when increasing the aggregate replacement ratio. Additionally, Ruiz-Herrero et al. [64] observed increases to carbonation depths in concrete containing PVC aggregates. This was attributed to the presence of chlorine ion in the PVC and higher porosity of the concrete.

The thermal performance of concrete and mortar positively benefit from the addition of PAs and PFs. Thermal conductivity decreases with increasing aggregate replacement ratio $[63,64,80-83]$ and fiber volume fraction [84,85]. Iucolano et al. [81] reported an almost 50\% reduction in conductivity when replacing only $20 \%$ of sand in mortar with mostly polyolefin aggregates. Ruiz-Herrero et al. [64] found a $67 \%$ drop in the thermal conductivity of mortar with aggregates replaced with $20 \%$ PVC and mixed PVC-PE, and Akçaözoğlu et al. [83] observed a 34.6\% reduction in thermal conductivity of concrete when replacing $30 \%$ of sand with PET aggregates. This improvement in thermal insulating 
behavior is generally attributed to the significantly lower conductivity of plastic particles when compared to natural aggregates, and due to the increased porosities of plastic mortars and concretes. However, Ruiz-Herero [64] posited that manifestation of a cellular structure in the mortar and concrete compositions also contributed to the substantial reduction in thermal conductivity. Contrary to the majority of experimental results, one study discovered a $12 \%$ increase in thermal conductivity when reinforcing concrete with nylon PFs [76].

The effects of pre-heating on the mechanical properties of concrete and mortars containing PAs were investigated $[70,71,86,87]$. Substituting NA with PAs leads to greater reductions in residual compressive strength, which is dependent on the pre-heating temperature level and type of plastic [87]. The higher degree of strength degradation for PA-based concretes was caused by the thermal decomposition of PAs, which resulted in the formation of additional voids consequently decreasing compressive strength further. Correia et al. [87] postulated that increases in porosity allow confined gases to disperse and reduce internal stress development caused by thermal incompatibility between the concrete constituents, which attenuates the development of cracks. The effects of elevated temperatures on the mass loss, residual compressive strength, and ultrasonic pulse velocity (UPV) of concrete reinforced with PP and MPW (LDPE) fibers were studied by Mohammadhosseini and Yatim [88] and Mohammadhosseini et al. [89], respectively. It was found that the incorporation of PP and MPW fibers significantly improved the concrete residual strength after elevated temperature exposure and did not exhibit spalling behavior. Liguori et al. [90] evaluated the thermal degradation and fire properties of composite mortars containing PET and polyolefin PAs. The time to ignition (TTI), heat release rate (HRR), and peak of heat release rate (pHRR) were measured using cone calorimetry. The inclusion of plastic content negatively influenced the fire resistance, with the composite mortars showing typical burning and pyrolysis behavior. Increasing the quantity of plastic content caused a reduction in TTI and an increase in PHRR. Despite this, the materials were classed as "low risk" based on the calculated flashover.

\section{Glass Waste in Concrete}

\subsection{Introduction}

Recycled glass represented an attractive option as a cement-based constituent over the past decade to researchers and engineers. Many research works investigated the potential of recycled glass to be utilized as an aggregate and/or cement substitute. The vast extant of research on this subject inspired the publication of many review papers in recent times [91-96]. In the following section, research published over the past decade on the incorporation of waste glass in concrete and mortars is reviewed. Glass waste as an aggregate and as a cementitious material forms the focus of the proceeding discussion with attention focused on research trends. The environmental, durability, and thermal performance of glass concrete and mortars are also reported.

Seventy research papers on the use of glass waste as a fine aggregate in cement-based concrete and mortars with the properties tested and application were reviewed, and listed in Table 2. Most research work (18 papers) originated from Hong Kong. The USA, China, and the UK produced six, six, and four works, respectively. All other countries provided three or fewer studies. The majority of papers did not specify the source of the waste glass (21), with beverage bottles/containers being the most popular source of waste glass (19), followed by cathode-ray tube (CRT) glass (10). In relation to material application, 26 studies were focused on OPC mortar, 20 on OPC concrete, 6 on lightweight concrete, and 5 on self-compacting concrete. Other, less studied applications included polymer concrete and self-compacting mortar. Forty of the reviewed works investigated aggregate replacement ratios up to $100 \%$ and 60 papers considered waste glass as a fine aggregate (sand) replacement. Only four studies substituted coarse aggregates with glass, and six research articles replaced both course and fine aggregates. 
On the use of glass waste as a cementitious material in concretes and mortars, 78 research papers were reviewed from 2009 to 2019 . The UK produced the most research with eight papers. The USA, Tunisia, Thailand, Taiwan, and Spain followed with seven, seven, six, five, and five publications, respectively. All other countries produced four or fewer studies. Thirty of the reviewed works did not specify the origin of the glass waste and 21 recycled beverage bottles. Other types of glass included windshields, LCDs, fluorescent lamps, and unspecified soda-lime glass. The most common maximum cement replacement ratios were $20 \%, 30 \%, 40 \%$, and $25 \%$, with $22,12,9$, and 7 papers adopting them. OPC concrete and mortar were the subject of investigation in most reviewed studies, featuring in 28 and 23 papers, respectively. Geopolymer mortar, self-compacting concrete (SCC), and ultra-high performance (UHP) concrete mixes followed with six, three, and three publications, respectively.

\subsection{Sustainability Aspects of Using Glass Waste in Concrete}

\subsubsection{Environmental Performance}

Hossain et al. conducted an LCA on the production of fine aggregates from recycled Construction and Demolition (C\&D) and glass waste in Hong Kong [97]. The authors reported that producing fine aggregates from glass waste can reduce greenhouse gas (GHG) emissions by $61 \%, \mathrm{SO}_{2}$ emissions by $46 \%$, and energy consumption by $54 \%$. However, this study was not extended to concrete or mortar production. Rashid et al. [98] determined the $\mathrm{CO}_{2}$ footprint of concrete containing glass aggregates as a substitute for natural fine and course aggregates. A linear relationship between $\mathrm{CO}_{2}$ emission reductions and aggregate replacement ratio was observed, with $30 \%$ aggregate replaced, equating to a $17 \%$ reduction in emissions of the concrete mix. Jiang et al. [99] conducted an LCA of conventional, glass powder (GP), and alkali-activated slag concrete and compared the cradle-to-grate greenhouse gas (GHG) emissions, energy use, water consumption, and environmental toxicity for $1 \mathrm{~m}^{3}$ of $35 \mathrm{MPa}$ concrete. A hybrid method was developed which combined the process-based and economic input-output LCA methods. On average, GP concrete reduces GHS emissions by $19 \%$, consumes $17 \%$ less energy and $14 \%$ less water, and features $14-21 \%$ lower environmental toxicity for $35 \mathrm{MPa}$ strength. The authors discovered that improvements in environmental performance increased with concrete strength. However, the upper bounds of environmental impacts of GP concrete could be larger than that of traditional concrete due to changes in technology and location of cement production.

\subsubsection{Durability Properties and Thermal/Fire Performance}

Opposing effects for shrinkage have been observed when incorporating glass aggregates in concrete and mortar mixtures. Some researchers have reported increases in shrinkage when increasing volumes of waste glass [100-102], whilst others have found reduced shrinkage [103-108]. Wang [109] and Wang et al. [107] recorded a non-linear relationship between shrinkage strain of concrete and glass powder content. Calmon et al. [110], Patel et al. [111], and Liu et al. [112] found an increase in drying shrinkage with glass powder content. Conversely, Lu et al. [113] observed a reduction in drying shrinkage with incorporating glass powder as a cement substitute. Concrete and mortars absorb less total water when possessing glass aggregates [114,115] despite an increase to IRA caused by a higher porosity [103]. de Castro and de Brito [116] investigated the water absorption by immersion of concrete containing glass aggregates and obtained very similar results when compared to the control sample which contained no glass. Finer glass aggregates lead to greater water absorption due to higher surface areas which trap more air [117]. However, Penacho et al. [102] and Wright et al. [106] observed reductions in water absorption by capillary action and sorptivity when increasing the glass replacement ratio. Bisht and Ramana [118] recorded increases to water absorption, water permeability, and sorptivity when incorporating glass aggregates into concrete as a fine aggregate substitute. Water absorption and IRA may increase with glass powder content $[60,119]$ followed by a reduction at higher dosages [110]. A reverse trend has been found by other authors [120-125]. 
Resistance to sulfate corrosion improves $[100,104,107]$ with the incorporation of glass aggregates, negligible or reduced chloride-ion penetration $[106,126]$, and small changes to carbonation depth occur $[116,127]$, whilst substitution of cement with glass powder improves chloride ion penetration, carbonation depth, water penetration depth, and sulfate resistance [107,109,120,121,128-133]. These enhancements to chemical resistance are due to a refined microstructure at the interfacial transition zone [120,132].

The damaging Alkali-silica reaction (ASR) is a major concern when incorporating glass aggregates into concrete and mortar mixtures due to their silica-rich and amorphous nature. The siliceous gel produced from the reaction between the silica in the aggregates and the calcium hydroxide cement absorbs water and swells, which may lead to micro-cracking in the glass and thus compromise the concrete or mortar material [91]. The significance of ASR is dependent on the quantity of glass aggregates incorporated, the particle size of the glass aggregates, and the type and color of glass. Generally, increases in the volume and particle size of waste glass lead to higher ASR expansion [105,134], though this may be color-dependent in the case of the former [132,135]. ASR may be suppressed or mitigated through the inclusion of various other admixtures, including Metakaolin (MK), fly ash, glass powder, silica-fume, and ground granulated blast-furnace slag (GGBS) [105,132,134,136-140].

The thermal and fire performance of glass aggregate concrete is less reported in the literature when compared to the mechanical, physical, and durability properties. Out of the 70 papers reviewed, 13 investigated thermal or fire properties. The literature shows that as the replacement ratio of waste glass to fine aggregate increases, thermal conductivity decreases [141-146]. This may be attributed to the lower density of concrete mixtures and higher porosity and thermal stability of glass when compared to natural fine aggregate. The use of glass aggregates may also reduce the coefficient of thermal expansion of concrete (COTE) $[106,126]$ due to the lower COTE of waste glass compared to sand and the reduced elastic modulus of glass aggregate concrete. Ling et al. [147] investigated the residual mechanical and durability properties of SCC with recycled glass aggregates in the place of sand after heating up to $800^{\circ} \mathrm{C}$. The inclusion of waste glass was found to reduce the damaging effects of high temperature exposure due to melting and subsequent resolidification of the glass aggregates, which had a pore and micro-crack filling effect.

\section{Fly Ash and Slag in Concrete}

Portland cement blended with supplementary cementitious materials (SCM) has been extensively integrated within concrete and cement-based materials worldwide. The common attraction of SCMs is their ability to reduce the amount of cement required in concrete as well as minimize the stock supply of waste materials such as fly ash and slag [148]. The addition of fly ash and slag creates a variation of hydration products when compared to traditional Portland cement. This was especially shown with calcium silicate hydrate (C-S-H), which was the primary component of strength and durability within concrete products [149]. The microstructure of cement blends with fly ash and slag was shown to create larger pore volumes within the cement matrix. However, the pore distributions were also finer. This correlates with a reduction of durability within concrete as the chemical transference was therefore greater, leading to enhanced chloride ion permeability and moisture integration [148]. When there was a higher porosity in the material, there was also a reduction in durability due to the higher water absorption activity. The increased absorption led to a reduction in compressive and flexural strength. However, this was commonly mitigated with the use of other SCMs such a silica fume in the form of a ternary blend [150].

High-temperature and fire performance of concrete containing SCMs has not been comprehensively investigated, especially when considering fly ash and slag. However, Zanjani et al. 2013 [149] compared the high-temperature performance of conventional concrete and fly ash- and slag-based concrete. When exposed to an elevated temperature of $300^{\circ} \mathrm{C}$, it was demonstrated that the nanoscale behavior of the different concrete blends was similar and did not show radical alterations. The mechanical difference between conventional and blended cements could not be identified after high-temperature 
exposure. However, the x-ray diffraction (XRD) analysis could determine that blended cements were slightly more temperature sensitive due to the reduction of indentation hardness. When the temperature was increased to $400{ }^{\circ} \mathrm{C}, 600^{\circ} \mathrm{C}$, and $800{ }^{\circ} \mathrm{C}$, the reduction in mechanical properties was further evident in all types of concrete materials. Some research has shown that slag concrete features better fire resistance than fly ash concrete [148]. It was commonly concluded that the higher percentage of fly ash and slag within concrete decreases the durability and mechanical properties. This was also shown with a decrease of resistance when exposed to high temperatures [148-151].

\subsection{Fly Ash in Concrete Materials}

The inclusion of fly ash in concrete materials has been extensively researched due to the positive environmental effects and similar characteristics of Portland cement. The production of Portland cement represents $7 \%-10 \%$ of total carbon dioxide emissions worldwide and therefore, utilizing fly ash is becoming increasingly important to lower the rate of global warming and enhance the emissions target of the Paris agreement [152,153]. Fly ash is the residue generated from coal combustion produced for electricity and heating purposes. The residue is taken before it is emitted into the atmosphere and can contain high amounts of silicon or varying contents of calcium. The mineral properties and fineness of fly ash react effectively with calcium oxide and water to create pozzolanic properties and result in the formation of a paste. There are typically two types of fly ash: Class $C$ and Class F. These classes are based on the type of coal burned in production. However, a worldwide standardization of fly ash has been difficult to implement due to the uncertainty of the chemical reaction within concrete applications. The physical and chemical material properties vary due to the type of coal, boiler machinery, and previous operating conditions used when in production [152-154]. The approximate production of fly ash is currently 2.8 billion metric tons per year, most coal-fired plants are equipped to meet government regulations that are put forth to reduce carbon emissions. Therefore, coal will continue to be used for many years to come [152].

Currently, fly ash has not been completely utilized within concrete compositions. The material characteristics can be limited due to the quality with fineness and unburned coal content. Further areas of investigation include the research of activating methods such as mechanical and chemical agents. Enhancing the mechanical properties within concrete has been shown with various chemical additives, however, the water requirements often increase. Standardization during manufacturing techniques could enhance the fly ash classifications; this can be shown with the granule sizes before it is included within a concrete mix design. Research conducted by Xu, G. and X. Shi 2018 [154] showed that the existing American society for testing and materials (ASTM) fly ash classifications are not meeting current industry requirements. This is due to the inability to classify fly ash with the reactivity once incorporated in concrete applications.

\subsection{Sustainability Aspects of Using Fly Ash in Concrete}

The inclusion of fly ash in concrete results in extensive environmental benefits such as reduction in cement production, greenhouse gas emissions, energy consumption, and solid waste creation [155]. Fly ash also contains positive effects during the hydration process within concrete. However, it was found that the inclusion of fly ash can create further water demand within concrete applications [156]. There has been significant research in the area of superplasticizers to reduce the increase of water demand, but the inclusion is not often met due to the additional costs and environmental burdens it can incur for the client [156]. Although the inclusion of fly ash can reduce the carbon footprint of concrete, with up to $40 \%$ compared to traditional Portland cement, research showed the additives used within fly ash concrete applications can often include a $20 \%$ cost increase and also potentially contribute to additional environmental implications $[5,16,152]$. It was often assumed with previous research including recycled aggregate and fly ash that costs will reduce as well as improving environmental performance. However, due to the limitation availability of activating agents such as sodium hydroxide, only $7 \%$ replacement of Portland cement is currently being implemented [152]. With the limiting 
utilization of fly ash, the material is often stored at power stations and disposal sites, water is combined with the fineness of fly ash and is often stored underground. This can pose as a threat to the environment and animal and human life in the surrounding area due to the potential soil contamination if not stored correctly [152,157]. Xu and Shi [154] showed that the sustainability of large-scale applications with fly ash needs to be further quantified in the areas of health risks, regulation compliance, and heavy metal leaching.

\subsection{Slag in Concrete Materials}

A primary concern within the steel industry has been to reduce the waste created during the production and manufacturing of steel products. In order to recycle the waste, extensive research has been conducted on incorporating slag in various concrete applications via partial cement replacement or partial aggregate replacement [158]. Slag materials were also included in the areas of agriculture with soil improvement and fertilizer, marine environments, and civil infrastructure including road and asphalt concrete $[158,159]$. The effectiveness of slag materials in concrete applications can vary due to the chemical composition of the material and the manufacturing process. Therefore, slag can be further categorized into three specific types: air-cooled blast furnace slag, pelletized slag, and granulated blast furnace slag. The different forms of slag are the excess by-products created during the refinement process within iron production [159]. There has been extensive research conducted combining slag materials with fly ash to reduce the consumption of both cement and aggregates in concrete. Although granulated blast furnace slag can be used as a partial cement replacement, it was shown that larger pellets can be incorporated as an aggregate [160]. There are approximately 20 million tons of slag produced annually in the United States and Europe, with an estimation of 288 million tons worldwide [161]. Even with the large supply of slag it could not currently compete with the annual requirements of Portland cement worldwide.

\subsection{Sustainability Aspects of Using Slag in Concrete}

Numerous research studies have focused on the positive minimization effects slag could have on the environment. With as much as $65 \%$ of slag incorporated in cement, there is a potential to eliminate $42-48 \%$ of carbon dioxide emissions created during cement production [162]. However, the literature research has not optimized the inclusion of slag with current and future climate change. Wang and Lee [163] focused on the carbonation effects of global warming during the curing of slag concrete and highlighted the requirements for admixtures and a richer mix of concrete. It is important to note that the temperature alternatives in the study were for regional conditions. In other recent studies, there has been significant research conducted to utilize two areas of concrete with replacing the aggregate and cement portions of a traditional concrete mix. Qasrawi [164] combined recycled aggregate such as construction and demolition rubble with steel slag aggregate. The inclusion of these materials degraded the workability of the concrete as well as reduced mechanical performance. However, in low-grade concrete and non-structural applications this could be effective method to reduce the negative effects created by these two materials. Excessive steel slag can pose an environmental threat on the surrounding area that it is stored in. Due to the impact it can have on ground penetration, the leaching of different metals into the underlying water can cause safety concerns to the local population and wildlife [159]. With the large annual generation of slag, a contemporary solution to effectively utilize a higher per cent in concrete is required. 
Table 2. Different types of minor waste products used in concrete.

\begin{tabular}{|c|c|c|c|c|}
\hline No & Waste Type & Main Study Focuses & Application/s & Reference/s \\
\hline \multirow{12}{*}{1} & \multirow{12}{*}{ Glass Aggregates } & Mechanical, physical, durability, and thermal properties & OPC Concrete & $\begin{array}{l}{[98,106,107,118,127,136-138,141,} \\
143,165-174]\end{array}$ \\
\hline & & Mechanical, physical, durability, and thermal properties & Lightweight Concrete & {$[134,142,175-178]$} \\
\hline & & Mechanical, physical, durability, and thermal properties & SC Concrete & {$[100,147,179-181]$} \\
\hline & & Mechanical, physical, durability, and thermal properties & Polymer Concrete & {$[115,144,182]$} \\
\hline & & Mechanical, physical, and durability properties & Concrete paving blocks & {$[115,116,183,184]$} \\
\hline & & Mechanical, physical, and durability properties & Concrete tiles, & [102] \\
\hline & & Mechanical, physical, and durability properties & Translucent and Photocatalytic & [139] \\
\hline & & Mechanical, physical, and durability properties & Concrete & [146] \\
\hline & & & Dry-mix Pervious Concrete & {$[101,103-105,108,113,114,117,126$, } \\
\hline & & Mechanical, physical, durability, and thermal properties & OPC Mortar & $132,135,145,185-198]$ \\
\hline & & Mechanical, physical, and durability properties & SC Mortar & {$[199,200]$} \\
\hline & & Mechanical and physical properties & Adhesive Mortar & [201] \\
\hline \multirow{12}{*}{2} & \multirow{12}{*}{ Glass Cement } & Mechanical, physical, durability, and thermal properties & OPC Concrete & \multirow{12}{*}{$\begin{array}{l}{[107,119,120,124,128,131,133,176,} \\
202-221] \\
{[121,222,223]} \\
{[224-227]} \\
{[228]} \\
{[229]} \\
{[230]} \\
{[60]} \\
{[231,232]} \\
{[109,111,112,122,123,125,129,130,} \\
191-197,233-240] \\
{[241-246]} \\
{[110,247]} \\
{[248-253]}\end{array}$} \\
\hline & & Mechanical, physical, and durability properties & SC Concrete & \\
\hline & & Mechanical and physical properties & High-performance Concrete & \\
\hline & & Mechanical, physical, and thermal properties & Polymer Concrete & \\
\hline & & Mechanical, physical, and durability properties & Concrete Pavements & \\
\hline & & Mechanical, physical, and durability properties & $\begin{array}{l}\text { Concrete slabs and walls } \\
\text { Dry-cast Concrete blocks }\end{array}$ & \\
\hline & & Mechanical, physical, and durability properties & $\begin{array}{l}\text { Dry-cast Concrete blocks } \\
\text { Concrete Beams and Columns }\end{array}$ & \\
\hline & & Mechanical properties & OPC Mortar & \\
\hline & & Mechanical, physical, durability, and thermal properties & & \\
\hline & & Mechanical, physical, and durability properties & $\begin{array}{l}\text { Geopolymer Mortar } \\
\text { Reinforced and repair Mortar }\end{array}$ & \\
\hline & & Mechanical, physical, and durability properties & Alkali-activated Mortar and & \\
\hline & & Mechanical and physical properties & $\begin{array}{l}\text { Alkan-activated Mlortar and } \\
\text { cement }\end{array}$ & \\
\hline \multirow{9}{*}{3} & \multirow{9}{*}{ Plastic Aggregates } & Mechanical, physical, durability, and thermal properties & OPC Concrete and mortar & {$[62,64,70,72,83,87,90,254-265]$} \\
\hline & & Mechanical and durability properties & Concrete footpaths & [266] \\
\hline & & Mechanical, physical, and durability properties & Concrete for dam repair & [79] \\
\hline & & Mechanical, physical, and durability properties & Dry-cast concrete blocks & [60] \\
\hline & & Mechanical, physical, durability, thermal, and acoustic properties & Lightweight concrete & {$[63,73,82,267]$} \\
\hline & & Mechanical, physical, and durability properties & SC concrete and mortar & {$[66,268-270]$} \\
\hline & & Mechanical & Polymer Concrete & [271] \\
\hline & & Mechanical, physical, durability, and thermal properties & OPC mortar & {$[61,67,71,81,272,273]$} \\
\hline & & Mechanical, physical, and durability properties & Lightweight mortar & {$[73,80]$} \\
\hline
\end{tabular}


Table 2. Cont

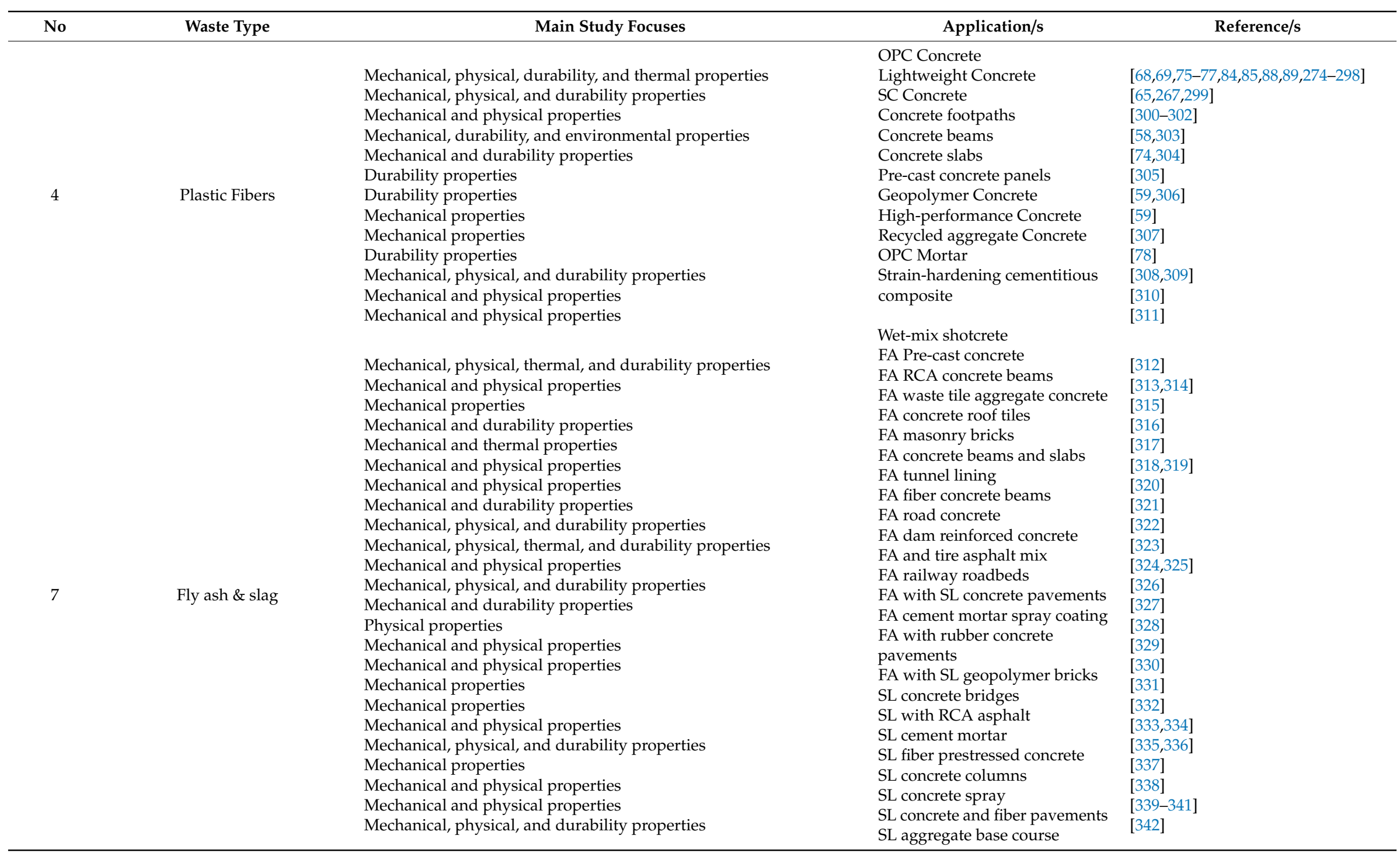




\section{Construction and Demolition (C\&D) Waste Reuse in Concrete}

\subsection{Introduction}

C\&D waste has been identified as the major solid waste type that contributes to significant environmental pollution [343,344]. Based on its composition, C\&D waste can be majorly categorized into masonry, concrete, stone, sand and gravel, wood, glass, plastic, and metal, and these inert materials can be effectively reused in building applications [345]. C\&D waste is a key waste type that can be reused in concrete applications, as its composition comprises cement and aggregate scraps which can be easily adopted as a replacement of virgin materials in concrete. Over the last decade, recycled C\&D waste has mainly been used as a coarse aggregate replacement material in concrete and is often called recycled concrete $[29,42,346]$. Concrete with recycled C\&D waste has been used in several applications. One study argued that closed loop recycling can attain better sustainable benefits as compared to open loop recycling [343].

\subsection{Sustainability Aspects of Using CED Waste in Concrete}

Several studies analyzed the environmental performance of using C\&D waste as means of reducing virgin material usage [345]. However, one study highlighted the issue of not considering energy-intensive practices required to process these waste materials into usable material [345]. Often, these energy-intensive aspects are neglected in benchmarking sustainable materials and it signifies the importance of a clear system boundary definition in analyzing sustainable benefits. The study further emphasized the importance of the application of ISO standards to facilitate control and management practices in order to minimize environmental impacts. C\&D waste applications vary significantly from packaging materials to road applications, and concrete use is observed majorly from C\&D waste obtained from the demolition of foundations, reinforced frames, and roadways [347].

Using a review, another study extensively investigated the use of recycled aggregate from C\&D waste in concrete [348]. The review documented satisfactory durability and strength performance of recycled concrete, including compressive strength, tensile and flexural strengths, creep, and shrinkage properties. Besides, another study in Spain characterized the use of recycled aggregate from C\&D waste in compliance with the Spanish Structural Code [349]. The results indicated that despite achieving material and strength characteristics, compliance guidelines of certain properties, such as chloride content and water absorption sulfur content, could not be achieved. Another study categorized aggregate from C\&D waste into recycled coarse aggregate, recycled masonry aggregate, and combination of both [350]. The study reported several observations on durability, fresh-state performance, and time-dependent performance of concrete with recycled aggregate materials. However, the sustainability considerations apart from the virgin material replacement were not investigated in the study. The sustainability focus was considered in 20 papers on C\&D waste in concrete, as illustrated in Figure 7. Based on these results, it is evident that major research focus was on the investigation of mechanical strength characteristics at laboratory scale, while few studies considered field investigations ( $5 \%$ of the total studies considered) and other sustainable considerations, including socio-economic benefits.

Despite the environmental benefits of virgin replacement of materials, some studies highlighted the challenges of using C\&D waste in building material applications [344]. According to these studies, the tipping fees and additional transportation costs are some economic implications that need to be considered and the importance of government incentives to promote the use of these waste materials was also highlighted. Another study emphasized the requirement to source the recycled materials locally to maximize the economic and environmental impacts [360]. Tam et al. [361] highlighted lack of standards, insufficient financial incentives, and customer perceptions as some of the major barriers that restrict the use of recycled aggregate from $C \& D$ waste in concrete. 


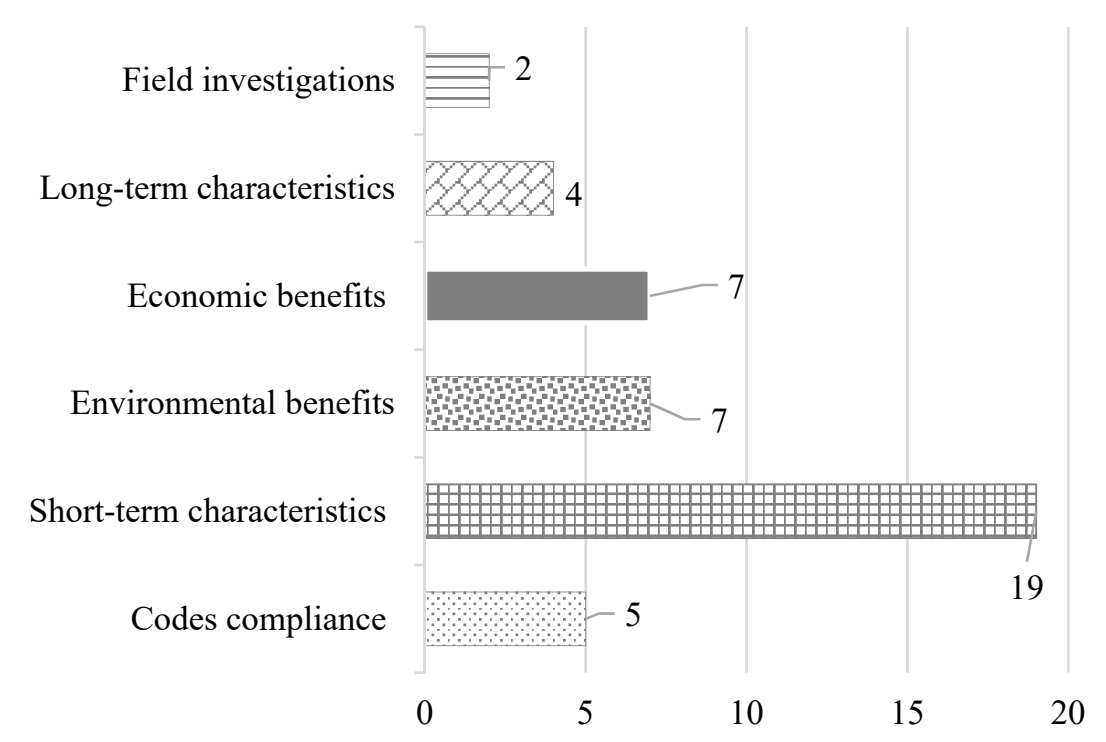

Figure 7. Sustainability focused studies with construction and demolition (C\&D) waste in concrete [42,346-373].

\section{Findings and Further Analysis}

The results from the in-depth review on selected waste materials highlighted key observations and gaps in current research which can assist researchers to identify future research avenues. Lack of LCA and LCC assessment on the use of waste materials in concrete to benchmark the life cycle savings is a major research gap area that demands further attention. Despite efforts by some recent studies to optimize environmental and economic benefits, the majority of the studies were only focused on analyzing greenhouse gas (GHG) emission savings due to virgin material replacement $[15,16,374-376]$. In addition, the review revealed that very limited studies were undertaken on thermal, acoustics, and fire properties of cementitious materials developed from waste materials such as glass, fly ash, and slag. Investigation of these properties are the key to promoting these materials in the commercial markets. The other two major research gaps are the lack of research studies on the bond strength of steel reinforcement embedded in concrete and the recyclability and reusability of concrete with plastic waste. Experimental behavior of these sustainable concrete mixes with reinforcement is critical, as it can benchmark the commercial possibilities of such products. This aspect is a key indicator that defines the overall strength and durability of the concrete when used in construction projects. Moreover, recyclability and reusability aspects of these waste materials also require significant investigation and can provide benchmark for long-term sustainable criterions such as sustainable disposal that leads to circular economy.

\subsection{Future Considerations and Discussions on Using Waste Products in Concrete}

Despite the positive results and trends, these sustainable alternatives are seldom developed into commercial products. Transition of a research product into a commercialized product is critical as it will provide opportunities for reaching the end-users of the product. To this end, a list of ten experts with related research expertise were consulted and face-to-face interviews were conducted to uncover the possibilities and barriers associated with commercializing sustainable concrete products in the building and construction industry. These stakeholders were selected based on their expertise and years of experience in the industry and research fields using waste materials in concrete. The composition of the interviewees is shown in Table 3. Participants were presented with an open-ended question mainly discussing the impediments to commercial implementation of waste materials. 
Table 3. Composition of the interviewed experts.

\begin{tabular}{|c|c|c|c|c|}
\hline \multirow{2}{*}{ Profession Type } & \multirow{2}{*}{ Areas of Experience } & \multicolumn{3}{|c|}{ Years of Experience } \\
\hline & & $0-5$ & $5-10$ & $10+$ \\
\hline Lecturer & $\begin{array}{l}\text { Research experience using waste materials in } \\
\text { cement replacement, fine aggregate and coarse } \\
\text { aggregate replacement in concrete. }\end{array}$ & & & 3 \\
\hline Research Fellow & $\begin{array}{l}\text { Research experience on waste materials as a } \\
\text { cement replacement in concrete. }\end{array}$ & 1 & 1 & \\
\hline $\begin{array}{l}\text { Production } \\
\text { Manager }\end{array}$ & $\begin{array}{l}\text { Industry experience on recycled materials for } \\
\text { production of concrete related products }\end{array}$ & 1 & & 2 \\
\hline $\begin{array}{l}\text { Construction } \\
\text { Manager }\end{array}$ & $\begin{array}{l}\text { Industry experience on concrete with recycled } \\
\text { aggregate, geo-polymer concrete, etc. }\end{array}$ & & 2 & \\
\hline
\end{tabular}

The interviews identified a number of factors that should be considered to enable promotion of products that incorporate waste materials as a commercially available construction material. Careful consideration of these factors would lead to more opportunities to commercialize such sustainable products.

\subsubsection{Investigation of Compliance Requirements of Materials}

The current decade review has highlighted that the majority of the available research on the use of waste materials in concrete focuses on short-term and long-term strength characteristics only [377-379]. A significant number of studies focused on environmental incentives of using these materials, including parameters like energy consumption and GHG emissions [4,375,380]. Still, the compliance requirements of these materials were seldom investigated [381,382]. However, according to the majority of the interviewees involved in this study, thermal conductivity, fire resistance, and acoustic properties are the key parameters required for the compliance check and declaration of a sustainable concrete product. The interviewees further emphasized that the simultaneous investigation of satisfactory compliance requirements is key to commercializing a sustainable concrete product. According to them, quite often these alternate concrete materials are not commercialized due to a lack of research findings on the compliance checks. Therefore, future studies should critically examine compliance requirements of sustainable concrete prior to its commercialization.

\subsubsection{Economic Benefits of Sustainable Materials}

The academic researchers in the interview group emphasized the cost of the final product as a major barrier that prevents industries from using sustainable concrete. They further stated that both end-users and manufacturers desire reduced costs and define the cost as a determining factor when it comes to launching a sustainable concrete product on the market. The interviewees acknowledged the importance of investigating LCC, however it was pointed out that the life cycle cost benefits are often secured by the client. Thus, the contractors are in favor of lowering the production, transportation, and handling costs of these materials. However, the use of waste materials often incurs additional manufacturing costs due to complex treatment processes, the addition of extra materials, and substances to activate concrete properties [5]. Therefore, research optimization studies are a necessity to strike the balance between the environmental benefits and production costs of these products.

\subsubsection{Availability of Waste Material and Demand}

Availability of waste materials was another criterion that was highlighted by the experts as a barrier that prevents the commercialization of a sustainable concrete product. This is due to manufacturers' preference to use locally available materials due to the reduced procurement and transportation costs. Availability of materials is also critical for efficient and interrupted production, while delays in procurement are likely to affect the manufacturers' cash flow. Moreover, use of locally available materials promotes environmental savings and sustainability. Therefore, local availability of waste materials is a key factor that requires consideration for developing sustainable concrete 
materials. This statement is particularly accurate in the case of using fly ash concrete, as per studies showing that non-availability of fly ash as a raw material affects environmental sustainability [5]. Therefore, availability of the waste material should clearly be defined as a key criterion when defining a sustainable concrete material.

\subsubsection{Quality Control Considerations}

Quality control was another key point highlighted by the industry professionals in the focus group. This is due to products with sustainable concrete often requiring additional long-term and short-term quality assurance checks in order to maintain the quality standards. For instance, lack of studies and knowledge on maintenance and future repair benchmarks of sustainable concrete requires construction stakeholders to establish additional long-term quality control and monitoring processes. This leads to additional costs and discourages industry stakeholders from replacing virgin materials with sustainable materials. According to the experts, these additional quality control measures are yet to be developed as guidelines and this represents another complication and prevents the possibility of budgeting the associated costs during bidding processes. Further research should be undertaken to investigate the life cycle aspects of these sustainable products. In particular, further research is required on handling and maintenance aspects. Similarly, the development of standards and guidelines for the use of these sustainable materials in concrete is an essential step forward.

\subsubsection{Social Acceptability}

Social acceptability was another aspect highlighted by the focus group attendees that will enable commercial possibilities for sustainable concrete manufactured from waste materials. According to them, community acceptance is a critical parameter that could accelerate the local councils and governments to promote such sustainable materials. High cost, durability aspects concerns, insufficient marketing, government initiatives, and negative perceptions are emphasized by the attendees as dominant reasons that influence wider social acceptability of sustainable materials. A potential solution would be to conduct social awareness programs at local, regional, and national level to promote benefits of such sustainable products, especially their long-term environmental benefits to the society. Providing financial incentives to people who wish to embrace these products was discussed as another potential solution likely to enhance the social acceptability of sustainable materials.

\subsubsection{Government Initiatives}

Despite the intensive research on sustainable concrete using waste materials, industries are quite often reluctant to adopt alternative materials unless there is a government initiative. One of the interviewed construction managers stated that industries often do not like to change their traditional methods unless there are some enforcements. Voluntary rating tools such as GreenStar and IS rating tools have taken notable initiatives to promote the use of sustainable materials by awarding additional points [383-385]. Despite these efforts, only passionate industries stakeholders committed to such efforts by using sustainable materials in their designs [386,387]. Therefore, it is important for local and federal governments to become involved and mandate the use of such sustainable materials in the construction industry to promote their use. Other alternative techniques, such as providing tax benefits or cash incentives, could also persuade the industries to adopt sustainable materials in construction.

\section{Conclusions, Limitations, and Future Research}

Concrete is the major material used in the building and construction industry, with significant production across the globe. Use of virgin materials for concrete production has been a major environmental burden due to resource depletion, high green gas emissions, and high energy consumption. Over the past decade numerous waste materials have been experimented with across the globe with an aim to replace virgin materials in concrete. 
- The current study aimed to review a decade of research studies on sustainable concrete which uses waste materials to replace virgin raw materials. Firstly, a bibliometric assessment was performed to identify the key research trends associated with sustainable concrete with waste materials. In the bibliometric assessment, 1465 research publications identified the most influential countries in undertaking experimental and analytical studies related to sustainable concrete. The results also highlighted journals with the most publications on sustainable concrete, authors with the most publications, and the publication trend within the last decade. Additionally, it was found that fly ash and recycled aggregate are the most researched waste materials, and that cement and aggregate substitutes have been the most popular applications. Only a few studies investigated the sustainable performance of concrete, with the research focus of majority of the studies consisting of experimental testing of mechanical and durability properties. Hence, it is recommended that future research efforts are made towards analyzing the economic, environmental, and social impacts of incorporating waste products in mortar and concrete mixes.

Based on the findings from the bibliometric assessment, an in-depth review of five key waste materials (plastic, glass, fly ash, slag and construction and demolition waste) used in concrete to replace virgin materials was undertaken. The objective of this review was to identify the current trends and research focuses on waste materials and to identify research gaps related to sustainability aspects. PET was the most common type of plastic adopted in experimental research and was often utilized as an aggregate replacement or as a fiber reinforcement. Numerous research articles have been published on the use of recycled glass, typically from drink bottles, as an aggregate and/or cement substitute. Research on recycling C\&D waste was focused on recycling concrete (cement and aggregate scraps) into aggregates that act as a substitute for virgin material. Fly ash and slag have been widely adopted as SCMs, though more research is needed on mechanical and chemical activation processes. Overall, the results highlighted a lack of research in LCA and LCC aspects, fire resistance, and acoustics, and the recyclability and reusability of the sustainable products. The review also identified a lack of transitional research that would enable further development of these materials into market-ready products. All these areas are required to be comprehensively researched in future studies. Subsequently, a group of interviewees, consisting of academics and construction industry professionals, were consulted to uncover the key factors that influence the possibility of commercializing sustainable concrete materials. The observations and opinions indicated six major impediments that prevent the commercialization of waste-incorporated sustainable concrete. The major impediments include economic benefits for builders, compliance requirements, quality control issues, social acceptability, and government initiatives. If these can be effectively addressed, transitioning these sustainable products into market-ready products could become a reality.

The current study inherited a number of limitations and assumptions. Future research and reviews can be performed to minimize these limitations and to draw more comprehensive findings in the field. The limitations and assumptions include:

- The findings of the review were based on the reviewed publications undertaken in the past decade only. Further analyses and interpretations can be undertaken by conducting reviews with a large timescale;

- The focus group interview included limited number of experts in the field and therefore further validation is encouraged in future studies to further justify or criticize the observations highlighted in the current study;

- The review only focused on the major waste types highlighted through the bibliometric analysis from Bibiliometrix.org. There could be other studies that use different waste materials in concrete and these could be of key relevance;

- The review investigated the current issues and considerations that could affect the commercialization of the building products manufactured from waste materials. However, these issues can change based on future changes in regulations. 
Despite these limitations, the current review attempted to inform the key findings and trends associated with sustainable concrete research in the past decade. The findings from this research will assist future researchers to understand the current and future directions in the field of sustainable concrete. Considering the current initiations in green construction and green rating systems, knowledge of sustainable concrete could provide key decisions on manufacturing and marketing sustainable materials. These findings also provide key pointers towards knowing how to translate the fundamental research on sustainable concrete into market ready products.

Author Contributions: Conceptualization, M.S., Y.B.; Methodology M.S.; Writing-original draft, M.S., Y.B., R.H.; Writing-review \& editing Z.V.; Funding acquisition, Z.V., M.S., Y.B. All authors have read and agreed the published version of the manuscript and provide consent for the accuracy.

Funding: The research is funded by Victoria University Research under the Planetary Health Research Grant awarded on 04/05/2020 as an internal grant.

Conflicts of Interest: The authors declare no conflict of interest.

\section{References}

1. Department of the Envrionment and Energy, Australian Government. Analysis of Australia's Municipal Recycling Infrastructure Capacity October 2018 Commonwealth of Australia 2018. Available online: https:/www.environment.gov.au/system/files/resources/f0196d2e-9040-4547-8cb6-8b433923b53d/ files/waste-stocktake-report.pdf (accessed on 11 August 2020).

2. Guo, Z.; Kong, X.; Zhang, J.; Sun, Y.; Tu, A.; Jiang, T. Life-cycle assessment of concrete building blocks incorporating recycled concrete aggregates-A case study in China. In Advances in Construction and Demolition Waste Recycling; Elsevier: Amsterdam, The Netherlands, 2020; pp. 515-535.

3. Birtles, B. Beijing Churns out 25,000 Tonnes of Rubbish Every Day-Here's How It Deals With its Waste Crisis. Available online: https://www.abc.net.au/news/2018-08-07/how-beijing-deals-with-waste-crisis/10078026 (accessed on 28 August 2020).

4. Luo, W.; Sandanayake, M.; Zhang, G. Direct and indirect carbon emissions in foundation construction-Two case studies of driven precast and cast-in-situ piles. J. Clean. Prod. 2019, 211, 1517-1526. [CrossRef]

5. Sandanayake, M.; Gunasekara, C.; Law, D.; Zhang, G.; Setunge, S. Greenhouse gas emissions of different fly ash based geopolymer concretes in building construction. J. Clean. Prod. 2018, 204, 399-408. [CrossRef]

6. Sandanayake, M.S. Models and Toolkit to Estimate and Analyse the Emissions and Environmental Impacts of Building Construction; Rmit University: Melbourne, Asutrlia, 2016.

7. Chau, C.K.; Yik, F.W.H.; Hui, W.K.; Liu, H.C.; Yu, H.K. Environmental impacts of building materials and building services components for commercial buildings in Hong Kong. J. Clean. Prod. 2007, 15, 1840-1851. [CrossRef]

8. Chau, C.K.; Hui, W.K.; Ng, W.Y.; Powell, G. Assessment of $\mathrm{CO}_{2}$ emissions reduction in high-rise concrete office buildings using different material use options. Resour. Conserv. Recycl. 2012, 61, 22-34. [CrossRef]

9. Ruth, M. Technology change in US iron and steel production: Implications for material and energy use, and $\mathrm{CO}_{2}$ emissions. Resour. Policy 1995, 21, 199-214. [CrossRef]

10. Hong, J.; Shen, G.Q.; Feng, Y.; Lau, W.S.-t.; Mao, C. Greenhouse gas emissions during the construction phase of a building: A case study in China. J. Clean. Prod. 2015, 103, 249-259. [CrossRef]

11. Yan, H.; Shen, Q.; Fan, L.C.H.; Wang, Y.; Zhang, L. Greenhouse gas emissions in building construction: A case study of One Peking in Hong Kong. Build. Environ. 2010, 45, 949-955. [CrossRef]

12. García-Segura, T.; Yepes, V.; Alcalá, J. Life cycle greenhouse gas emissions of blended cement concrete including carbonation and durability. Int. J. Life Cycle Assess. 2014, 19, 3-12. [CrossRef]

13. Fan, C.; Miller, S.A. Reducing greenhouse gas emissions for prescribed concrete compressive strength. Constr. Build. Mater. 2018, 167, 918-928. [CrossRef]

14. Sandanayake, M.; Lokuge, W.; Zhang, G.; Setunge, S.; Thushar, Q. Greenhouse gas emissions during timber and concrete building construction-A scenario based comparative case study. Sustain. Cities Soc. 2018, 38, 91-97. [CrossRef]

15. Huang, B.; Chen, Y.; McDowall, W.; Türkeli, S.; Bleischwitz, R.; Geng, Y. Embodied GHG emissions of building materials in Shanghai. J. Clean. Prod. 2019, 210, 777-785. [CrossRef] 
16. Sandanayake, M.; Gunasekara, C.; Law, D.; Zhang, G.; Setunge, S.; Wanijuru, D. Sustainable criterion selection framework for green building materials-An optimisation based study of fly-ash Geopolymer concrete. Sustain. Mater. Technol. 2020, 25, e00178. [CrossRef]

17. Hossain, M.U.; Poon, C.S. Comparative LCA of wood waste management strategies generated from building construction activities. J. Clean. Prod. 2018, 177, 387-397. [CrossRef]

18. Meyer, C. The greening of the concrete industry. Cem. Concr. Compos. 2009, 31, 601-605. [CrossRef]

19. Pahlevani, F.; Sahajwalla, V. From waste glass to building materials-An innovative sustainable solution for waste glass. J. Clean. Prod. 2018, 191, 192-206.

20. Lu, J.-X.; Poon, C.S. 6-Recycling of waste glass in construction materials. In New Trends in Eco-Efficient and Recycled Concrete; de Brito, J., Agrela, F., Eds.; Woodhead Publishing: Oxford, UK, 2019; pp. 153-167. [CrossRef]

21. Chandra, S. Waste Materials Used in Concrete Manufacturing; Elsevier: Amsterdam, The Netherlands, 1996.

22. Yahya, K.; Halim Boussabaine, A. Eco-costing of construction waste. Manag. Environ. Qual. Int. J. 2006, 17, 6-19. [CrossRef]

23. Solís-Guzmán, J.; Marrero, M.; Montes-Delgado, M.V.; Ramírez-de-Arellano, A. A Spanish model for quantification and management of construction waste. Waste Manag. 2009, 29, 2542-2548. [CrossRef]

24. Silva, R.V.; de Brito, J.; Dhir, R.K. Properties and composition of recycled aggregates from construction and demolition waste suitable for concrete production. Constr. Build. Mater. 2014, 65, 201-217. [CrossRef]

25. Sandanayake, M.; Zhang, G.; Setunge, S. Estimation of environmental emissions and impacts of building construction-A decision making tool for contractors. J. Build. Eng. 2018. [CrossRef]

26. Callejas, I.J.A.; Durante, L.C.; Oliveira, A.S.d. Thermal resistance and conductivity of recycled construction and demolition waste (RCDW) concrete blocks. Rem-Int. Eng. J. 2017, 70, 167-173. [CrossRef]

27. Cardoso, R.; Silva, R.V.; de Brito, J.; Dhir, R. Use of recycled aggregates from construction and demolition waste in geotechnical applications: A literature review. Waste Manag. 2016, 49, 131-145. [CrossRef] [PubMed]

28. Tabsh, S.W.; Abdelfatah, A.S. Influence of recycled concrete aggregates on strength properties of concrete. Constr. Build. Mater. 2009, 23, 1163-1167. [CrossRef]

29. Rao, A.; Jha, K.N.; Misra, S. Use of aggregates from recycled construction and demolition waste in concrete. Resour. Conserv. Recycl. 2007, 50, 71-81. [CrossRef]

30. Flower, D.J.; Sanjayan, J.G. Green house gas emissions due to concrete manufacture. Int. J. Life Cycle Assess. 2007, 12, 282-288. [CrossRef]

31. Kong, D.L.; Sanjayan, J.G. Effect of elevated temperatures on geopolymer paste, mortar and concrete. Cem. Concr. Res. 2010, 40, 334-339. [CrossRef]

32. Akadiri, P.O.; Olomolaiye, P.O.; Chinyio, E.A. Multi-criteria evaluation model for the selection of sustainable materials for building projects. Autom. Constr. 2013, 30, 113-125. [CrossRef]

33. Florez, L.; Castro-Lacouture, D. Optimization model for sustainable materials selection using objective and subjective factors. Mater. Des. 2013, 46, 310-321. [CrossRef]

34. Ramezanianpour, A.; Ghahari, S.; Ramezaninapour, A.; Esmaeili, K. Effect of steam curing on mechanical properties of self-compacting concrete containing pozzolan. Spec. Publ. 2015, 303, 45-56.

35. Ghahari, S.; Mohammadi, A.; Ramezanianpour, A. Performance assessment of natural pozzolan roller compacted concrete pavements. Case Stud. Constr. Mater. 2017, 7, 82-90. [CrossRef]

36. Sargam, Y.; Wang, K.; Alleman, J.E. Effects of modern concrete materials on thermal conductivity. J. Mater. Civ. Eng. 2020, 32, 04020058. [CrossRef]

37. Liu, J.-W.; Huang, L.-C. Detecting and visualizing emerging trends and transient patterns in fuel cell scientific literature. In Proceedings of the 2008 4th International Conference on Wireless Communications, Networking and Mobile Computing, Dalian, China, 12-17 October 2008; pp. 1-4.

38. Van Eck, N.J.; Waltman, L. Visualizing bibliometric networks. In Measuring Scholarly Impact; Springer: Berlin/Heidelberg, Germany, 2014; pp. 285-320.

39. Synnestvedt, M.B.; Chen, C.; Holmes, J.H. CiteSpace II: Visualization and knowledge discovery in bibliographic databases. In Proceedings of the AMIA Annual Symposium, Washington, DC, USA, 22-26 October 2005; p. 724.

40. Aria, M.; Cuccurullo, C. bibliometrix: An R-tool for comprehensive science mapping analysis. J. Informetr. 2017, 11, 959-975. [CrossRef] 
41. Saikia, N.; De Brito, J. Use of plastic waste as aggregate in cement mortar and concrete preparation: A review. Constr. Build. Mater. 2012, 34, 385-401. [CrossRef]

42. De Brito, J.; Saikia, N. Recycled Aggregate in Concrete: Use of Industrial, Construction and Demolition Waste; Springer Science \& Business Media: Berlin/Heidelberg, Germany, 2012.

43. Gu, L.; Ozbakkaloglu, T. Use of recycled plastics in concrete: A critical review. Waste Manag. 2016, 51, $19-42$. [CrossRef]

44. Sharma, R.; Bansal, P.P. Use of different forms of waste plastic in concrete-a review. J. Clean. Prod. 2016, 112, 473-482. [CrossRef]

45. Usman, A.; Sutanto, M.H.; Napiah, M. Effect of Recycled Plastic in Mortar and Concrete and the Application of Gamma Irradiation-A Review. In Proceedings of the E3S Web of Conferences, Polanica-Zdrój, Poland, 16-18 April 2018; p. 05027.

46. Merli, R.; Preziosi, M.; Acampora, A.; Lucchetti, M.C.; Petrucci, E. Recycled fibers in reinforced concrete: A systematic literature review. J. Clean. Prod. 2019, 248, 119207. [CrossRef]

47. Li, X.; Ling, T.-C.; Mo, K.H. Functions and impacts of plastic/rubber wastes as eco-friendly aggregate in concrete-A review. Constr. Build. Mater. 2020, 240, 117869. [CrossRef]

48. Faraj, R.H.; Ali, H.F.H.; Sherwani, A.F.H.; Hassan, B.R.; Karim, H. Use of recycled plastic in self-compacting concrete: A comprehensive review on fresh and mechanical properties. J. Build. Eng. 2020, 30, 101283. [CrossRef]

49. Jassim, A.K. Recycling of polyethylene waste to produce plastic cement. Procedia Manuf. 2017, 8, 635-642. [CrossRef]

50. Gesoglu, M.; Güneyisi, E.; Hansu, O.; Etli, S.; Alhassan, M. Mechanical and fracture characteristics of self-compacting concretes containing different percentage of plastic waste powder. Constr. Build. Mater. 2017, 140, 562-569. [CrossRef]

51. Schaefer, C.E.; Kupwade-Patil, K.; Ortega, M.; Soriano, C.; Büyüköztürk, O.; White, A.E.; Short, M.P. Irradiated recycled plastic as a concrete additive for improved chemo-mechanical properties and lower carbon footprint. Waste Manag. 2018, 71, 426-439. [CrossRef]

52. Mahdi, F.; Abbas, H.; Khan, A. Strength characteristics of polymer mortar and concrete using different compositions of resins derived from post-consumer PET bottles. Constr. Build. Mater. 2010, 24, 25-36. [CrossRef]

53. Mahdi, F.; Abbas, H.; Khan, A.A. Flexural, shear and bond strength of polymer concrete utilizing recycled resin obtained from post consumer PET bottles. Constr. Build. Mater. 2013, 44, 798-811. [CrossRef]

54. Agyeman, S.; Obeng-Ahenkora, N.; Assiamah, S.; Twumasi, G. Exploiting recycled plastic waste as an alternative binder for paving blocks production. Case Stud. Constr. Mater. 2019, 11, e00246. [CrossRef]

55. Foti, D.; Paparella, F. Impact behavior of structural elements in concrete reinforced with PET grids. Mech. Res. Commun. 2014, 57, 57-66. [CrossRef]

56. Foti, D. Innovative techniques for concrete reinforcement with polymers. Constr. Build. Mater. 2016, 112, 202-209. [CrossRef]

57. Dai, J.-G.; Bai, Y.-L.; Teng, J. Behavior and modeling of concrete confined with FRP composites of large deformability. J. Compos. Constr. 2011, 15, 963-973. [CrossRef]

58. Yin, S.; Tuladhar, R.; Sheehan, M.; Combe, M.; Collister, T. A life cycle assessment of recycled polypropylene fibre in concrete footpaths. J. Clean. Prod. 2016, 112, 2231-2242. [CrossRef]

59. Bhogayata, A.C.; Arora, N.K. Utilization of metalized plastic waste of food packaging articles in geopolymer concrete. J. Mater. Cycles Waste Manag. 2019, 21, 1014-1026. [CrossRef]

60. Chidiac, S.; Mihaljevic, S. Performance of dry cast concrete blocks containing waste glass powder or polyethylene aggregates. Cem. Concr. Compos. 2011, 33, 855-863. [CrossRef]

61. Hannawi, K.; Kamali-Bernard, S.; Prince, W. Physical and mechanical properties of mortars containing PET and PC waste aggregates. Waste Manag. 2010, 30, 2312-2320. [CrossRef]

62. Silva, R.V.; de Brito, J.; Saikia, N. Influence of curing conditions on the durability-related performance of concrete made with selected plastic waste aggregates. Cem. Concr. Compos. 2013, 35, 23-31. [CrossRef]

63. Colangelo, F.; Cioffi, R.; Liguori, B.; Iucolano, F. Recycled polyolefins waste as aggregates for lightweight concrete. Compos. Part B Eng. 2016, 106, 234-241. [CrossRef] 
64. Ruiz-Herrero, J.L.; Nieto, D.V.; López-Gil, A.; Arranz, A.; Fernández, A.; Lorenzana, A.; Merino, S.; De Saja, J.A.; Rodríguez-Pérez, M.Á. Mechanical and thermal performance of concrete and mortar cellular materials containing plastic waste. Constr. Build. Mater. 2016, 104, 298-310. [CrossRef]

65. Sadrmomtazi, A.; Sobhani, J.; Mirgozar, M.; Najimi, M. Properties of multi-strength grade EPS concrete containing silica fume and rice husk ash. Constr. Build. Mater. 2012, 35, 211-219. [CrossRef]

66. Sadrmomtazi, A.; Dolati-Milehsara, S.; Lotfi-Omran, O.; Sadeghi-Nik, A. The combined effects of waste Polyethylene Terephthalate (PET) particles and pozzolanic materials on the properties of self-compacting concrete. J. Clean. Prod. 2016, 112, 2363-2373. [CrossRef]

67. Ge, Z.; Huang, D.; Sun, R.; Gao, Z. Properties of plastic mortar made with recycled polyethylene terephthalate. Constr. Build. Mater. 2014, 73, 682-687. [CrossRef]

68. Mohammadhosseini, H.; Yatim, J.M.; Sam, A.R.M.; Awal, A.A. Durability performance of green concrete composites containing waste carpet fibers and palm oil fuel ash. J. Clean. Prod. 2017, 144, 448-458. [CrossRef]

69. Mohammadhosseini, H.; Tahir, M.M. Durability performance of concrete incorporating waste metalized plastic fibres and palm oil fuel ash. Constr. Build. Mater. 2018, 180, 92-102. [CrossRef]

70. Zéhil, G.-P.; Assaad, J.J. Feasibility of concrete mixtures containing cross-linked polyethylene waste materials. Constr. Build. Mater. 2019, 226,1-10. [CrossRef]

71. Ghernouti, Y.; Rabehi, B. Strength and durability of mortar made with plastics bag waste (MPBW). Int. J. Concr. Struct. Mater. 2012, 6, 145-153. [CrossRef]

72. Frigione, M. Recycling of PET bottles as fine aggregate in concrete. Waste Manag. 2010, 30, 1101-1106. [CrossRef] [PubMed]

73. Akçaözoğlu, S.; Atiş, C.D.; Akçaözoğlu, K. An investigation on the use of shredded waste PET bottles as aggregate in lightweight concrete. Waste Manag. 2010, 30, 285-290. [CrossRef] [PubMed]

74. Kim, S.B.; Yi, N.H.; Kim, H.Y.; Kim, J.-H.J.; Song, Y.-C. Material and structural performance evaluation of recycled PET fiber reinforced concrete. Cem. Concr. Compos. 2010, 32, 232-240. [CrossRef]

75. Awal, A.; Mohammadhosseini, H.; Hossain, M.Z. Strength, modulus of elasticity and shrinkage behaviour of concrete containing waste carpet fiber. Int. J. Geomate 2015, 9, 1441-1446.

76. Ozger, O.; Girardi, F.; Giannuzzi, G.; Salomoni, V.; Majorana, C.; Fambri, L.; Baldassino, N.; Di Maggio, R. Effect of nylon fibres on mechanical and thermal properties of hardened concrete for energy storage systems. Mater. Des. 2013, 51, 989-997. [CrossRef]

77. Pešić, N.; Živanović, S.; Garcia, R.; Papastergiou, P. Mechanical properties of concrete reinforced with recycled HDPE plastic fibres. Constr. Build. Mater. 2016, 115, 362-370. [CrossRef]

78. Wu, X.; Zhou, J.; Kang, T.; Wang, F.; Ding, X.; Wang, S. Laboratory Investigation on the Shrinkage Cracking of Waste Fiber-Reinforced Recycled Aggregate Concrete. Materials 2019, 12, 1196. [CrossRef]

79. Galvão, J.C.A.; Portella, K.F.; Joukoski, A.; Mendes, R.; Ferreira, E.S. Use of waste polymers in concrete for repair of dam hydraulic surfaces. Constr. Build. Mater. 2011, 25, 1049-1055. [CrossRef]

80. Coppola, B.; Courard, L.; Michel, F.; Incarnato, L.; Scarfato, P.; Di Maio, L. Hygro-thermal and durability properties of a lightweight mortar made with foamed plastic waste aggregates. Constr. Build. Mater. 2018, 170, 200-206. [CrossRef]

81. Iucolano, F.; Liguori, B.; Caputo, D.; Colangelo, F.; Cioffi, R. Recycled plastic aggregate in mortars composition: Effect on physical and mechanical properties. Mater. Des. (1980-2015) 2013, 52, 916-922. [CrossRef]

82. D'Alessandro, F.; Asdrubali, F.; Baldinelli, G. Multi-parametric characterization of a sustainable lightweight concrete containing polymers derived from electric wires. Constr. Build. Mater. 2014, 68, 277-284. [CrossRef]

83. Akçaözoğlu, S.; Akçaözoğlu, K.; Atiş, C.D. Thermal conductivity, compressive strength and ultrasonic wave velocity of cementitious composite containing waste PET lightweight aggregate (WPLA). Compos. Part B Eng. 2013, 45, 721-726. [CrossRef]

84. Fraternali, F.; Ciancia, V.; Chechile, R.; Rizzano, G.; Feo, L.; Incarnato, L. Experimental study of the thermo-mechanical properties of recycled PET fiber-reinforced concrete. Compos. Struct. 2011, 93, 2368-2374. [CrossRef]

85. Poonyakan, A.; Rachakornkij, M.; Wecharatana, M.; Smittakorn, W. Potential Use of Plastic Wastes for Low Thermal Conductivity Concrete. Materials 2018, 11, 1938. [CrossRef]

86. Saxena, R.; Siddique, S.; Gupta, T.; Sharma, R.K.; Chaudhary, S. Impact resistance and energy absorption capacity of concrete containing plastic waste. Constr. Build. Mater. 2018, 176, 415-421. [CrossRef] 
87. Correia, J.; Lima, J.; de Brito, J. Post-fire mechanical performance of concrete made with selected plastic waste aggregates. Cem. Concr. Compos. 2014, 53, 187-199. [CrossRef]

88. Mohammadhosseini, H.; Yatim, J.M. Microstructure and residual properties of green concrete composites incorporating waste carpet fibers and palm oil fuel ash at elevated temperatures. J. Clean. Prod. 2017, 144, 8-21. [CrossRef]

89. Mohammadhosseini, H.; Tahir, M.M.; Alyousef, R.; Alabduljabbar, H.; Samadi, M. Effect of elevated temperatures on properties of sustainable concrete composites incorporating waste metalized plastic fibres. Sn Appl. Sci. 2019, 1, 1520. [CrossRef]

90. Liguori, B.; Iucolano, F.; Capasso, I.; Lavorgna, M.; Verdolotti, L. The effect of recycled plastic aggregate on chemico-physical and functional properties of composite mortars. Mater. Des. 2014, 57, 578-584. [CrossRef]

91. Paul, S.C.; Šavija, B.; Babafemi, A.J. A comprehensive review on mechanical and durability properties of cement-based materials containing waste recycled glass. J. Clean. Prod. 2018, 198, 891-906. [CrossRef]

92. Jani, Y.; Hogland, W. Waste glass in the production of cement and concrete-A review. J. Environ. Chem. Eng. 2014, 2, 1767-1775. [CrossRef]

93. Rashad, A.M. Recycled waste glass as fine aggregate replacement in cementitious materials based on Portland cement. Constr. Build. Mater. 2014, 72, 340-357. [CrossRef]

94. Paris, J.M.; Roessler, J.G.; Ferraro, C.C.; DeFord, H.D.; Townsend, T.G. A review of waste products utilized as supplements to Portland cement in concrete. J. Clean. Prod. 2016, 121, 1-18. [CrossRef]

95. Jiang, Y.; Ling, T.-C.; Mo, K.H.; Shi, C.J.J.O.E.M. A critical review of waste glass powder-Multiple roles of utilization in cement-based materials and construction products. J. Environ. Manag. 2019, 242, 440-449. [CrossRef] [PubMed]

96. Yao, Z.; Ling, T.-C.; Sarker, P.; Su, W.; Liu, J.; Wu, W.; Tang, J. Recycling difficult-to-treat e-waste cathode-ray-tube glass as construction and building materials: A critical review. Renew. Sustain. Energy Rev. 2018, 81, 595-604. [CrossRef]

97. Hossain, M.U.; Poon, C.S.; Lo, I.M.; Cheng, J.C. Comparative environmental evaluation of aggregate production from recycled waste materials and virgin sources by LCA. Resour. Conserv. Recycl. 2016, 109, 67-77. [CrossRef]

98. Rashid, K.; Hameed, R.; Ahmad, H.A.; Razzaq, A.; Ahmad, M.; Mahmood, A. Analytical framework for value added utilization of glass waste in concrete: Mechanical and environmental performance. Waste Manag. 2018, 79, 312-323. [CrossRef]

99. Jiang, M.; Chen, X.; Rajabipour, F.; Hendrickson, C.T. Comparative life cycle assessment of conventional, glass powder, and alkali-activated slag concrete and mortar. J. Infrastruct. Syst. 2014, 20, 04014020. [CrossRef]

100. Wang, H.-Y.; Huang, W.-L. Durability of self-consolidating concrete using waste LCD glass. Constr. Build. Mater. 2010, 24, 1008-1013. [CrossRef]

101. Hui, Z.; Sun, W. Study of properties of mortar containing cathode ray tubes (CRT) glass as replacement for river sand fine aggregate. Constr. Build. Mater. 2011, 25, 4059-4064. [CrossRef]

102. Penacho, P.; de Brito, J.; Veiga, M.R. Physico-mechanical and performance characterization of mortars incorporating fine glass waste aggregate. Cem. Concr. Compos. 2014, 50, 47-59. [CrossRef]

103. Ling, T.-C.; Poon, C.-S.; Kou, S.-C. Feasibility of using recycled glass in architectural cement mortars. Cem. Concr. Compos. 2011, 33, 848-854. [CrossRef]

104. Ling, T.-C.; Poon, C.-S. Properties of architectural mortar prepared with recycled glass with different particle sizes. Mater. Des. 2011, 32, 2675-2684. [CrossRef]

105. Ling, T.-C.; Poon, C.-S. Utilization of recycled glass derived from cathode ray tube glass as fine aggregate in cement mortar. J. Hazard. Mater. 2011, 192, 451-456. [CrossRef] [PubMed]

106. Wright, J.R.; Cartwright, C.; Fura, D.; Rajabipour, F. Fresh and hardened properties of concrete incorporating recycled glass as 100\% sand replacement. J. Mater. Civ. Eng. 2014, 26, 04014073. [CrossRef]

107. Wang, H.-Y.; Zeng, H.-h.; Wu, J.-Y. A study on the macro and micro properties of concrete with LCD glass. Constr. Build. Mater. 2014, 50, 664-670. [CrossRef]

108. Choi, S.Y.; Choi, Y.S.; Yang, E.I. Characteristics of volume change and heavy metal leaching in mortar specimens recycled heavyweight waste glass as fine aggregate. Constr. Build. Mater. 2018, 165, 424-433. [CrossRef] 
109. Wang, H.-Y. The effect of the proportion of thin film transistor-liquid crystal display (TFT-LCD) optical waste glass as a partial substitute for cement in cement mortar. Constr. Build. Mater. 2011, 25, 791-797. [CrossRef]

110. Calmon, J.L.; Sauer, A.S.; Vieira, G.L.; Teixeira, J.E.S.L. Effects of windshield waste glass on the properties of structural repair mortars. Cem. Concr. Compos. 2014, 53, 88-96. [CrossRef]

111. Patel, D.; Tiwari, R.; Shrivastava, R.; Yadav, R. Effective utilization of waste glass powder as the substitution of cement in making paste and mortar. Constr. Build. Mater. 2019, 199, 406-415. [CrossRef]

112. Liu, G.; Florea, M.; Brouwers, H.J.C.; Materials, B. Performance evaluation of sustainable high strength mortars incorporating high volume waste glass as binder. Constr. Build. Mater. 2019, 202, 574-588. [CrossRef]

113. Lu, J.-X.; Zhan, B.-J.; Duan, Z.-H.; Poon, C.S. Improving the performance of architectural mortar containing 100\% recycled glass aggregates by using SCMs. Constr. Build. Mater. 2017, 153, 975-985. [CrossRef]

114. Mardani-Aghabaglou, A.; Tuyan, M.; Ramyar, K. Mechanical and durability performance of concrete incorporating fine recycled concrete and glass aggregates. Mater. Struct. 2015, 48, 2629-2640. [CrossRef]

115. Zegardło, B.; Szelag,, M.; Ogrodnik, P.; Bombik, A. Physico-mechanical properties and microstructure of polymer concrete with recycled glass aggregate. Materials 2018, 11, 1213. [CrossRef]

116. De Castro, S.; de Brito, J. Evaluation of the durability of concrete made with crushed glass aggregates. J. Clean. Prod. 2013, 41, 7-14. [CrossRef]

117. Ling, T.-C.; Poon, C.-S. Effects of particle size of treated CRT funnel glass on properties of cement mortar. Mater. Struct. 2013, 46, 25-34. [CrossRef]

118. Bisht, K.; Ramana, P. Sustainable production of concrete containing discarded beverage glass as fine aggregate. Constr. Build. Mater. 2018, 177, 116-124. [CrossRef]

119. Elaqra, H.A.; Abou Haloub, M.A.; Rustom, R.N.J.C.; Materials, B. Effect of new mixing method of glass powder as cement replacement on mechanical behavior of concrete. Constr. Build. Mater. 2019, 203, 75-82. [CrossRef]

120. Du, H.; Tan, K.H. Transport properties of concrete with glass powder as supplementary cementitious material. Aci Mater. J. 2015, 112, 429. [CrossRef]

121. Matos, A.M.; Ramos, T.; Nunes, S.; Sousa-Coutinho, J.J.M.R. Durability enhancement of SCC with waste glass powder. Mater. Res. 2016, 19, 67-74. [CrossRef]

122. Parghi, A.; Alam, M.S. Physical and mechanical properties of cementitious composites containing recycled glass powder (RGP) and styrene butadiene rubber (SBR). Constr. Build. Mater. 2016, 104, 34-43. [CrossRef]

123. Matos, A.M.; Sousa-Coutinho, J.J.A.I.C.R. Waste glass powder in cement: Macro and micro scale study. Adv. Cem. Res. 2016, 28, 423-432. [CrossRef]

124. Ramakrishnan, K.; Pugazhmani, G.; Sripragadeesh, R.; Muthu, D.; Venkatasubramanian, C.J.C.; Materials, B. Experimental study on the mechanical and durability properties of concrete with waste glass powder and ground granulated blast furnace slag as supplementary cementitious materials. Constr. Build. Mater. 2017, 156, 739-749. [CrossRef]

125. Younes, M.; Abdel-Rahman, H.; Khattab, M.M. Utilization of rice husk ash and waste glass in the production of ternary blended cement mortar composites. J. Build. Eng. 2018, 20, 42-50. [CrossRef]

126. Guo, M.-Z.; Chen, Z.; Ling, T.-C.; Poon, C.S. Effects of recycled glass on properties of architectural mortar before and after exposure to elevated temperatures. J. Clean. Prod. 2015, 101, 158-164. [CrossRef]

127. Limbachiya, M.; Meddah, M.S.; Fotiadou, S. Performance of granulated foam glass concrete. Constr. Build. Mater. 2012, 28, 759-768. [CrossRef]

128. Jain, J.A.; Neithalath, N.J.C.; Composites, C. Chloride transport in fly ash and glass powder modified concretes-influence of test methods on microstructure. Cem. Concr. Compos. 2010, 32, 148-156. [CrossRef]

129. Matos, A.M.; Sousa-Coutinho, J. Durability of mortar using waste glass powder as cement replacement. Constr. Build. Mater. 2012, 36, 205-215. [CrossRef]

130. Carsana, M.; Frassoni, M.; Bertolini, L. Comparison of ground waste glass with other supplementary cementitious materials. Cem. Concr. Compos. 2014, 45, 39-45. [CrossRef]

131. Kim, J.; Moon, J.-H.; Shim, J.W.; Sim, J.; Lee, H.-G.; Zi, G. Durability properties of a concrete with waste glass sludge exposed to freeze-and-thaw condition and de-icing salt. Constr. Build. Mater. 2014, 66, 398-402. [CrossRef]

132. Du, H.; Tan, K.H. Use of waste glass as sand in mortar: Part I - Fresh, mechanical and durability properties. Cem. Concr. Compos. 2013, 35, 109-117. [CrossRef] 
133. Du, H.; Tan, K.H. Properties of high volume glass powder concrete. Cem. Concr. Compos. 2017, 75, $22-29$. [CrossRef]

134. Lee, G.; Ling, T.-C.; Wong, Y.-L.; Poon, C.-S. Effects of crushed glass cullet sizes, casting methods and pozzolanic materials on ASR of concrete blocks. Constr. Build. Mater. 2011, 25, 2611-2618. [CrossRef]

135. Du, H.; Tan, K.H. Effect of particle size on alkali-silica reaction in recycled glass mortars. Constr. Build. Mater. 2014, 66, 275-285. [CrossRef]

136. Zhao, H.; Poon, C.S.; Ling, T.C. Utilizing recycled cathode ray tube funnel glass sand as river sand replacement in the high-density concrete. J. Clean. Prod. 2013, 51, 184-190. [CrossRef]

137. Almesfer, N.; Ingham, J. Effect of waste glass on the properties of concrete. J. Mater. Civ. Eng. 2014, 26, 06014022. [CrossRef]

138. Cota, F.P.; Melo, C.C.D.; Panzera, T.H.; Araújo, A.G.; Borges, P.H.R.; Scarpa, F. Mechanical properties and ASR evaluation of concrete tiles with waste glass aggregate. Sustain. Cities Soc. 2015, 16, 49-56. [CrossRef]

139. Spiesz, P.; Rouvas, S.; Brouwers, H. Utilization of waste glass in translucent and photocatalytic concrete. Constr. Build. Mater. 2016, 128, 436-448. [CrossRef]

140. Du, H.; Tan, K.H. Use of waste glass as sand in mortar: Part II-Alkali-silica reaction and mitigation methods. Cem. Concr. Compos. 2013, 35, 118-126. [CrossRef]

141. Borhan, T.M. Properties of glass concrete reinforced with short basalt fibre. Mater. Des. 2012, 42, $265-271$. [CrossRef]

142. Al-Sibahy, A.; Edwards, R. Mechanical and thermal properties of novel lightweight concrete mixtures containing recycled glass and metakaolin. Constr. Build. Mater. 2012, 31, 157-167. [CrossRef]

143. Krishnamoorthy, R.R.; Zujip, J.A. Thermal conductivity and microstructure of concrete using recycle glass as a fine aggregate replacement. Int. J. Emerg. Technol. Adv. Eng. 2013, 3, 463-471.

144. Chung, S.-Y.; Abd Elrahman, M.; Sikora, P.; Rucinska, T.; Horszczaruk, E.; Stephan, D. Evaluation of the effects of crushed and expanded waste glass aggregates on the material properties of lightweight concrete using image-based approaches. Materials 2017, 10, 1354. [CrossRef] [PubMed]

145. Sikora, P.; Horszczaruk, E.; Skoczylas, K.; Rucinska, T. Thermal properties of cement mortars containing waste glass aggregate and nanosilica. Procedia Eng. 2017, 196, 159-166. [CrossRef]

146. Lu, J.-X.; Yan, X.; He, P.; Poon, C.S. Sustainable design of pervious concrete using waste glass and recycled concrete aggregate. J. Clean. Prod. 2019, 234, 1102-1112. [CrossRef]

147. Ling, T.-C.; Poon, C.-S.; Kou, S.-C. Influence of recycled glass content and curing conditions on the properties of self-compacting concrete after exposure to elevated temperatures. Cem. Concr. Compos. 2012, 34, 265-272. [CrossRef]

148. Karahan, O. Transport properties of high volume fly ash or slag concrete exposed to high temperature. Constr. Build. Mater. 2017, 152, 898-906. [CrossRef]

149. Zanjani Zadeh, V.; Bobko, C.P. Nanoscale mechanical properties of concrete containing blast furnace slag and fly ash before and after thermal damage. Cem. Concr. Compos. 2013, 37, 215-221. [CrossRef]

150. Guo, Z.; Jiang, T.; Zhang, J.; Kong, X.; Chen, C.; Lehman, D.E. Mechanical and durability properties of sustainable self-compacting concrete with recycled concrete aggregate and fly ash, slag and silica fume. Constr. Build. Mater. 2020, 231, 117115. [CrossRef]

151. Gopalakrishnan, R.; Chinnaraju, K. Durability of ambient cured alumina silicate concrete based on slag/fly ash blends against sulfate environment. Constr. Build. Mater. 2019, 204, 70-83. [CrossRef]

152. Assi, L.N.; Carter, K.; Deaver, E.; Ziehl, P. Review of availability of source materials for geopolymer/sustainable concrete. J. Clean. Prod. 2020, 263, 121477. [CrossRef]

153. Miller, S.A.; Horvath, A.; Monteiro, P.J.M. Readily implementable techniques can cut annual CO2 emissions from the production of concrete by over $20 \%$. Environ. Res. Lett. 2016, 11. [CrossRef]

154. Xu, G.; Shi, X. Characteristics and applications of fly ash as a sustainable construction material: A state-of-the-art review. Resour. Conserv. Recycl. 2018, 136, 95-109. [CrossRef]

155. Nath, P.; Sarker, P.K.; Biswas, W.K. Effect of fly ash on the service life, carbon footprint and embodied energy of high strength concrete in the marine environment. Energy Build. 2018, 158, 1694-1702. [CrossRef]

156. Durán-Herrera, A.; Juárez, C.A.; Valdez, P.; Bentz, D.P. Evaluation of sustainable high-volume fly ash concretes. Cem. Concr. Compos. 2011, 33, 39-45. [CrossRef] 
157. Kaufman, R. Seeking A Safer Future for Electricity's Coal Ash Waste National Geographic [WWW Document] URL. 2011. Available online: https://www.nationalgeographic.com/news/energy/2011/08/110815-safer-waysto-reycle-fly-ash-from-coal/ (accessed on 12 August 2020).

158. Fisher, L.V.; Barron, A.R. The recycling and reuse of steelmaking slags-A review. Resour. Conserv. Recycl. 2019, 146, 244-255. [CrossRef]

159. Jiang, Y.; Ling, T.-C.; Shi, C.; Pan, S.-Y. Characteristics of steel slags and their use in cement and concrete-A review. Resour. Conserv. Recycl. 2018, 136, 187-197. [CrossRef]

160. Habert, G.; d'Espinose de Lacaillerie, J.B.; Roussel, N. An environmental evaluation of geopolymer based concrete production: Reviewing current research trends. Clean. Prod. 2011, 19, 1229-1238. [CrossRef]

161. Guo, J.; Bao, Y.; Wang, M. Steel slag in China: Treatment, recycling, and management. Waste Manag. 2018, 78, 318-330. [CrossRef]

162. Berndt, M.L. Influence of concrete mix design on $\mathrm{CO}_{2}$ emissions for large wind turbine foundations. Renew. Energy 2015, 83, 608-614. [CrossRef]

163. Wang, X.-Y.; Lee, H.-S. Effect of global warming on the proportional design of low $\mathrm{CO}_{2}$ slag-blended concrete. Constr. Build. Mater. 2019, 225, 1140-1151. [CrossRef]

164. Qasrawi, H. The use of steel slag aggregate to enhance the mechanical properties of recycled aggregate concrete and retain the environment. Constr. Build. Mater. 2014, 54, 298-304. [CrossRef]

165. Saccani, A.; Bignozzi, M.C. ASR expansion behavior of recycled glass fine aggregates in concrete. Cem. Concr. Res. 2010, 40, 531-536. [CrossRef]

166. Rajabipour, F.; Maraghechi, H.; Fischer, G. Investigating the alkali-silica reaction of recycled glass aggregates in concrete materials. J. Mater. Civ. Eng. 2010, 22, 1201-1208. [CrossRef]

167. Mageswari, M.; Vidivelli, D.B. The use of sheet glass powder as fine aggregate replacement in concrete. Open Civ. Eng. J. 2010, 4, 65-71. [CrossRef]

168. Tuan, B.L.A.; Hwang, C.-L.; Lin, K.-L.; Chen, Y.-Y.; Young, M.-P. Development of lightweight aggregate from sewage sludge and waste glass powder for concrete. Constr. Build. Mater. 2013, 47, 334-339. [CrossRef]

169. Saribiyik, M.; Piskin, A.; Saribiyik, A. The effects of waste glass powder usage on polymer concrete properties. Constr. Build. Mater. 2013, 47,840-844. [CrossRef]

170. Adaway, M.; Wang, Y. Recycled glass as a partial replacement for fine aggregate in structural concrete-Effects on compressive strength. Electron. J. Struct. Eng. 2015, 14, 116-122.

171. Choi, S.Y.; Choi, Y.S.; Yang, E.I. Effects of heavy weight waste glass recycled as fine aggregate on the mechanical properties of mortar specimens. Ann. Nucl. Energy 2017, 99, 372-382. [CrossRef]

172. Malik, M.I.; Bashir, M.; Ahmad, S.; Tariq, T.; Chowdhary, U. Study of concrete involving use of waste glass as partial replacement of fine aggregates. Iosr J. Eng. 2013, 3, 8-13. [CrossRef]

173. Abdallah, S.; Fan, M. Characteristics of concrete with waste glass as fine aggregate replacement. Int. J. Eng. Tech. Res. (Ijetr) 2014, 2, 11-17.

174. Ling, T.-C.; Poon, C.-S. Feasible use of recycled CRT funnel glass as heavyweight fine aggregate in barite concrete. J. Clean. Prod. 2012, 33, 42-49. [CrossRef]

175. Hunag, L.-J.; Wang, H.-Y.; Wang, S.-Y. A study of the durability of recycled green building materials in lightweight aggregate concrete. Constr. Build. Mater. 2015, 96, 353-359. [CrossRef]

176. Liu, S.; Xie, G.; Wang, S. Effect of curing temperature on hydration properties of waste glass powder in cement-based materials. J. Therm. Anal. Calorim. 2015, 119, 47-55. [CrossRef]

177. Liu, S.; Wang, S.; Tang, W.; Hu, N.; Wei, J. Inhibitory effect of waste glass powder on ASR expansion induced by waste glass aggregate. Materials 2015, 8, 6849-6862. [CrossRef]

178. Yu, R.; Van Onna, D.; Spiesz, P.; Yu, Q.; Brouwers, H. Development of ultra-lightweight fibre reinforced concrete applying expanded waste glass. J. Clean. Prod. 2016, 112, 690-701. [CrossRef]

179. Liu, M. Incorporating ground glass in self-compacting concrete. Constr. Build. Mater. 2011, 25, 919-925. [CrossRef]

180. Arabi, N.; Meftah, H.; Amara, H.; Kebaili, O.; Berredjem, L. Valorization of recycled materials in development of self-compacting concrete: Mixing recycled concrete aggregates-Windshield waste glass aggregates. Constr. Build. Mater. 2019, 209, 364-376. [CrossRef]

181. Ali, E.E.; Al-Tersawy, S.H. Recycled glass as a partial replacement for fine aggregate in self compacting concrete. Constr. Build. Mater. 2012, 35, 785-791. [CrossRef] 
182. Kou, S.-C.; Poon, C.-S. A novel polymer concrete made with recycled glass aggregates, fly ash and metakaolin. Constr. Build. Mater. 2013, 41, 146-151. [CrossRef]

183. Ling, T.-C.; Poon, C.-S. Use of recycled CRT funnel glass as fine aggregate in dry-mixed concrete paving blocks. J. Clean. Prod. 2014, 68, 209-215. [CrossRef]

184. Chen, Z.; Li, J.S.; Poon, C.S. Combined use of sewage sludge ash and recycled glass cullet for the production of concrete blocks. J. Clean. Prod. 2018, 171, 1447-1459. [CrossRef]

185. Liu, T.; Song, W.; Zou, D.; Li, L. Dynamic mechanical analysis of cement mortar prepared with recycled cathode ray tube (CRT) glass as fine aggregate. J. Clean. Prod. 2018, 174, 1436-1443. [CrossRef]

186. Ling, T.-C.; Poon, C.-S. A comparative study on the feasible use of recycled beverage and CRT funnel glass as fine aggregate in cement mortar. J. Clean. Prod. 2012, 29, 46-52. [CrossRef]

187. Ling, T.-C.; Poon, C.-S.; Lam, W.-S.; Chan, T.-P.; Fung, K.K.-L. Utilization of recycled cathode ray tubes glass in cement mortar for X-ray radiation-shielding applications. J. Hazard. Mater. 2012, 199, 321-327. [CrossRef]

188. Maraghechi, H.; Fischer, G.; Rajabipour, F. The role of residual cracks on alkali silica reactivity of recycled glass aggregates. Cem. Concr. Compos. 2012, 34, 41-47. [CrossRef]

189. Serpa, D.; Silva, A.S.; De Brito, J.; Pontes, J.; Soares, D. ASR of mortars containing glass. Constr. Build. Mater. 2013, 47, 489-495. [CrossRef]

190. Arulrajah, A.; Disfani, M.M.; Haghighi, H.; Mohammadinia, A.; Horpibulsuk, S. Modulus of rupture evaluation of cement stabilized recycled glass/recycled concrete aggregate blends. Constr. Build. Mater. 2015, 84, 146-155. [CrossRef]

191. Afshinnia, K.; Rangaraju, P.R. Influence of fineness of ground recycled glass on mitigation of alkali-silica reaction in mortars. Constr. Build. Mater. 2015, 81, 257-267. [CrossRef]

192. Guo, S.; Dai, Q.; Sun, X.; Xiao, X.; Si, R.; Wang, J. Reduced alkali-silica reaction damage in recycled glass mortar samples with supplementary cementitious materials. J. Clean. Prod. 2018, 172, 3621-3633. [CrossRef]

193. Lu, J.-x.; Duan, Z.-H.; Poon, C.S. Combined use of waste glass powder and cullet in architectural mortar. Cem. Concr. Compos. 2017, 82, 34-44. [CrossRef]

194. Lu, J.-x.; Duan, Z.-h.; Poon, C.S. Fresh properties of cement pastes or mortars incorporating waste glass powder and cullet. Constr. Build. Mater. 2017, 131, 793-799. [CrossRef]

195. Lu, J.-X.; Zhan, B.-J.; Duan, Z.-H.; Poon, C.S. Using glass powder to improve the durability of architectural mortar prepared with glass aggregates. Mater. Des. 2017, 135, 102-111. [CrossRef]

196. Lu, J.-X.; Poon, C.S. Improvement of early-age properties for glass-cement mortar by adding nanosilica. Cem. Concr. Compos. 2018, 89, 18-30. [CrossRef]

197. Lu, J.-X.; Poon, C.S. Use of waste glass in alkali activated cement mortar. Constr. Build. Mater. 2018, 160, 399-407. [CrossRef]

198. Tan, K.H.; Du, H. Concrete with Recycled Glass as Fine Aggregates. ACI Mater. J. 2014, 111, 47-57.

199. Idir, R.; Cyr, M.; Tagnit-Hamou, A. Use of fine glass as ASR inhibitor in glass aggregate mortars. Constr. Build. Mater. 2010, 24, 1309-1312. [CrossRef]

200. Tuaum, A.; Shitote, S.; Oyawa, W. Experimental study of self-compacting mortar incorporating recycled glass aggregate. Buildings 2018, 8, 15. [CrossRef]

201. De Azevedo, A.R.G.; Alexandre, J.; Zanelato, E.B.; Marvila, M.T. Influence of incorporation of glass waste on the rheological properties of adhesive mortar. Constr. Build. Mater. 2017, 148, 359-368. [CrossRef]

202. Aly, M.; Hashmi, M.; Olabi, A.; Messeiry, M.; Hussain, A. Effect of nano clay particles on mechanical, thermal and physical behaviours of waste-glass cement mortars. Mater. Sci. Eng. A 2011, 528, 7991-7998. [CrossRef]

203. Aly, M.; Hashmi, M.; Olabi, A.; Messeiry, M.; Abadir, E.; Hussain, A. Effect of colloidal nano-silica on the mechanical and physical behaviour of waste-glass cement mortar. Mater. Des. 2012, 33, 127-135. [CrossRef]

204. Khatib, J.; Negim, E.; Sohl, H.; Chileshe, N. Glass powder utilisation in concrete production. Eur. J. Appl. Sci. 2012, 4, 173-176.

205. Vijayakumar, G.; Vishaliny, H.; Govindarajulu, D. Studies on glass powder as partial replacement of cement in concrete production. Int. J. Emerg. Technol. Adv. Eng. 2013, 3, 153-157.

206. Madandoust, R.; Ghavidel, R. Mechanical properties of concrete containing waste glass powder and rice husk ash. Biosyst. Eng. 2013, 116, 113-119. [CrossRef]

207. Du, H.; Tan, K.H. Waste glass powder as cement replacement in concrete. J. Adv. Concr. Technol. 2014, 12, 468-477. [CrossRef] 
208. Jang, H.; Jeon, S.; So, H.; So, S. Properties of different particle size of recycled TFT-LCD waste glass powder as a cement concrete binder. Int. J. Precis. Eng. Manuf. 2015, 16, 2591-2597. [CrossRef]

209. Kara, P. The influence of waste glass slurry on the properties of concrete. Int. J. Appl. Innov. Eng. Manag. (Ijaiem) 2013, 2, 325-330.

210. Aliabdo, A.A.; Abd Elmoaty, M.; Aboshama, A.Y. Utilization of waste glass powder in the production of cement and concrete. Constr. Build. Mater. 2016, 124, 866-877. [CrossRef]

211. Afshinnia, K.; Rangaraju, P.R. Impact of combined use of ground glass powder and crushed glass aggregate on selected properties of Portland cement concrete. Constr. Build. Mater. 2016, 117, 263-272. [CrossRef]

212. Sakale, R.; Jain, S.; Singh, S. Experimental investigation on strength of glass powder replacement by cement in concrete with different dosages. Int. J. Adv. Res. Comput. Sci. Softw. Eng. 2015, 5, 386-390.

213. Anwar, A. The influence of waste glass powder as a pozzolanic material in concrete. Int. J. Civ. Eng. Technol. (Ijciet) 2016, 7, 131-148.

214. Islam, G.S.; Rahman, M.; Kazi, N. Waste glass powder as partial replacement of cement for sustainable concrete practice. Int. J. Sustain. Built Environ. 2017, 6, 37-44. [CrossRef]

215. AL-Zubaid, A.B.; Shabeeb, K.M.; Ali, A.I. Study the effect of recycled glass on the mechanical properties of green concrete. Energy Procedia 2017, 119, 680-692. [CrossRef]

216. Kim, S.K.; Kang, S.T.; Kim, J.K.; Jang, I.Y.J.A.i.M.S. Effects of particle size and cement replacement of LCD glass powder in concrete. Adv. Mater. Sci. Eng. 2017, 2017, 3928047. [CrossRef]

217. Olofinnade, O.M.; Ede, A.N.; Ndambuki, J.M.J.I.J.O.E.; Innovation, T. Experimental investigation on the effect of elevated temperature on compressive strength of concrete containing waste glass powder. Int. J. Eng. Technol. Innov. 2017, 7, 280-291.

218. Lee, H.; Hanif, A.; Usman, M.; Sim, J.; Oh, H. Performance evaluation of concrete incorporating glass powder and glass sludge wastes as supplementary cementing material. J. Clean. Prod. 2018, 170, 683-693. [CrossRef]

219. Ramdani, S.; Guettala, A.; Benmalek, M.; Aguiar, J.B.J.J.O.B.E. Physical and mechanical performance of concrete made with waste rubber aggregate, glass powder and silica sand powder. J. Build. Eng. 2019, 21, 302-311. [CrossRef]

220. He, Z.-H.; Zhan, P.-M.; Du, S.-G.; Liu, B.-J.; Yuan, W.-B.J.C.P.B.E. Creep behavior of concrete containing glass powder. Compos. Part B Eng. 2019, 166, 13-20. [CrossRef]

221. Khan, Q.S.; Sheikh, M.N.; McCarthy, T.J.; Robati, M.; Allen, M.J.C.; Materials, B. Experimental investigation on foam concrete without and with recycled glass powder: A sustainable solution for future construction. Constr. Build. Mater. 2019, 201,369-379. [CrossRef]

222. Kara, P. Recycling of Glass Wastes in Latvia-Its Application as Cement Substitute in Self-Compacting Concrete. J. Sustain. Archit. Civ. Eng. 2014, 6, 42-49. [CrossRef]

223. Sharifi, Y.; Afshoon, I.; Firoozjaie, Z.J.J.O.A.C.T. Fresh properties of self-compacting concrete containing ground waste glass microparticles as cementing material. J. Adv. Concr. Technol. 2015, 13, 50-66. [CrossRef]

224. Kou, S.C.; Xing, F. The effect of recycled glass powder and reject fly ash on the mechanical properties of fibre-reinforced ultrahigh performance concrete. Adv. Mater. Sci. Eng. 2012, 2012, 263243. [CrossRef]

225. Soliman, N.; Tagnit-Hamou, A. Development of ultra-high-performance concrete using glass powder-Towards ecofriendly concrete. Constr. Build. Mater. 2016, 125, 600-612. [CrossRef]

226. Soliman, N.; Tagnit-Hamou, A.J.C.; Materials, B. Partial substitution of silica fume with fine glass powder in UHPC: Filling the micro gap. Constr. Build. Mater. 2017, 139, 374-383. [CrossRef]

227. Vaitkevičius, V.; Šerelis, E.; Hilbig, H. The effect of glass powder on the microstructure of ultra high performance concrete. Constr. Build. Mater. 2014, 68, 102-109. [CrossRef]

228. Xuan, D.; Tang, P.; Poon, C.S. MSWIBA-based cellular alkali-activated concrete incorporating waste glass powder. Cem. Concr. Compos. 2019, 95, 128-136. [CrossRef]

229. Nassar, R.-U.-D.; Soroushian, P. Field investigation of concrete incorporating milled waste glass. J. Solid Waste Technol. Manag. 2011, 37, 307-319. [CrossRef]

230. Omran, A.F.; Etienne, D.; Harbec, D.; Tagnit-Hamou, A.J.C.; Materials, B. Long-term performance of glass-powder concrete in large-scale field applications. Constr. Build. Mater. 2017, 135, 43-58. [CrossRef]

231. Hama, S.M.; Mahmoud, A.S.; Yassen, M.M. Flexural behavior of reinforced concrete beam incorporating waste glass powder. In Proceedings of the Structures, Orlando, FL, USA, 24-29 April 2019; pp. 510-518.

232. Niang, A.; Roy, N.; Tagnit-Hamou, A.J.J.O.S.E. Structural behavior of concrete incorporating glass powder used in reinforced concrete columns. J. Struct. Eng. 2015, 141, B4014007. [CrossRef] 
233. Jang, B.-K.; Lee, J.-C.; Kim, J.-H.; Chung, C.-W.J.A.R. Enhancement of thermal neutron shielding of cement mortar by using borosilicate glass powder. Appl. Radiat. Isot. 2017, 123, 1-5. [CrossRef]

234. Pereira-de-Oliveira, L.A.; Castro-Gomes, J.P.; Santos, P.M. The potential pozzolanic activity of glass and red-clay ceramic waste as cement mortars components. Constr. Build. Mater. 2012, 31, 197-203. [CrossRef]

235. Khmiri, A.; Samet, B.; Chaabouni, M. A cross mixture design to optimise the formulation of a ground waste glass blended cement. Constr. Build. Mater. 2012, 28, 680-686. [CrossRef]

236. Idir, R.; Cyr, M.; Tagnit-Hamou, A. Pozzolanic properties of fine and coarse color-mixed glass cullet. Cem. Concr. Compos. 2011, 33, 19-29. [CrossRef]

237. Khmiri, A.; Chaabouni, M.; Samet, B. Chemical behaviour of ground waste glass when used as partial cement replacement in mortars. Constr. Build. Mater. 2013, 44, 74-80. [CrossRef]

238. Mirzahosseini, M.; Riding, K.A. Effect of curing temperature and glass type on the pozzolanic reactivity of glass powder. Cem. Concr. Res. 2014, 58, 103-111. [CrossRef]

239. Kim, J.; Yi, C.; Zi, G. Waste glass sludge as a partial cement replacement in mortar. Constr. Build. Mater. 2015, 75, 242-246. [CrossRef]

240. Šimonová, H.; Zahálková, J.; Rovnaníková, P.; Bayer, P.; Keršner, Z.; Schmid, P.J.P.E. Mechanical fracture parameters of cement based mortars with waste glass powder. Procedia Eng. 2017, 190, 86-91. [CrossRef]

241. Pascual, A.B.; Tognonvi, M.T.; Tagnit-Hamou, A. Waste glass powder-based alkali-activated mortar. Int. J. Res. Eng. Technol 2014, 3, 32-36.

242. Torres-Carrasco, M.; Puertas, F.J.J.O.C.P. Waste glass in the geopolymer preparation. Mechanical and microstructural characterisation. J. Clean. Prod. 2015, 90, 397-408. [CrossRef]

243. Vafaei, M.; Allahverdi, A.J.J.O.M.I.C.E. Durability of geopolymer mortar based on waste-glass powder and calcium aluminate cement in acid solutions. J. Mater. Civ. Eng. 2017, 29, 04017196. [CrossRef]

244. Vafaei, M.; Allahverdi, A. High strength geopolymer binder based on waste-glass powder. Adv. Powder Technol. 2017, 28, 215-222. [CrossRef]

245. Vafaei, M.; Allahverdi, A.; Dong, P.; Bassim, N.J.C.; Materials, B. Acid attack on geopolymer cement mortar based on waste-glass powder and calcium aluminate cement at mild concentration. Constr. Build. Mater. 2018, 193, 363-372. [CrossRef]

246. Tho-In, T.; Sata, V.; Boonserm, K.; Chindaprasirt, P.J.J.O.C.P. Compressive strength and microstructure analysis of geopolymer paste using waste glass powder and fly ash. J. Clean. Prod. 2018, 172, 2892-2898. [CrossRef]

247. Criado, M.; García-Díaz, I.; Bastidas, J.; Alguacil, F.J.; López, F.; Monticelli, C.J.C.; Materials, B. Effect of recycled glass fiber on the corrosion behavior of reinforced mortar. Constr. Build. Mater. 2014, 64, 261-269. [CrossRef]

248. Vinai, R.; Soutsos, M.J.C.; Research, C. Production of sodium silicate powder from waste glass cullet for alkali activation of alternative binders. Cem. Concr. Res. 2019, 116, 45-56. [CrossRef]

249. Torres-Carrasco, M.; Rodríguez-Puertas, C.; del Mar Alonso, M.; Puertas, F.J.B.D.L.S.E.D.C.Y.V. Alkali activated slag cements using waste glass as alternative activators. Rheological behaviour. Boletín Soc. Española Ceram. Vìdrio 2015, 54, 45-57. [CrossRef]

250. Zhang, S.; Keulen, A.; Arbi, K.; Ye, G. Waste glass as partial mineral precursor in alkali-activated slag/fly ash system. Cem. Concr. Res. 2017, 102, 29-40. [CrossRef]

251. Bignozzi, M.; Saccani, A.; Barbieri, L.; Lancellotti, I. Glass waste as supplementary cementing materials: The effects of glass chemical composition. Cem. Concr. Compos. 2015, 55, 45-52. [CrossRef]

252. Zheng, K.J.C.; Composites, C. Pozzolanic reaction of glass powder and its role in controlling alkali-silica reaction. Cem. Concr. Compos. 2016, 67, 30-38. [CrossRef]

253. Mirzahosseini, M.; Riding, K.A.J.C.; Composites, C. Influence of different particle sizes on reactivity of finely ground glass as supplementary cementitious material (SCM). Cem. Concr. Compos. 2015, 56, 95-105. [CrossRef]

254. Rahmani, E.; Dehestani, M.; Beygi, M.; Allahyari, H.; Nikbin, I. On the mechanical properties of concrete containing waste PET particles. Constr. Build. Mater. 2013, 47, 1302-1308. [CrossRef]

255. Senthil Kumar, K.; Baskar, K. Response surfaces for fresh and hardened properties of concrete with e-waste (HIPS). J. Waste Manag. 2014. [CrossRef]

256. Aldahdooh, M.; Jamrah, A.; Alnuaimi, A.; Martini, M.; Ahmed, M.; Ahmed, A. Influence of various plastics-waste aggregates on properties of normal concrete. J. Build. Eng. 2018, 17, 13-22. [CrossRef] 
257. De la Colina Martínez, A.L.; Barrera, G.M.; Díaz, C.E.B.; Córdoba, L.I.Á.; Núñez, F.U.; Hernández, D.J.D. Recycled polycarbonate from electronic waste and its use in concrete: Effect of irradiation. Constr. Build. Mater. 2019, 201, 778-785. [CrossRef]

258. Ferreira, L.; de Brito, J.; Saikia, N. Influence of curing conditions on the mechanical performance of concrete containing recycled plastic aggregate. Constr. Build. Mater. 2012, 36, 196-204. [CrossRef]

259. Liu, F.; Yan, Y.; Li, L.; Lan, C.; Chen, G. Performance of recycled plastic-based concrete. J. Mater. Civ. Eng. 2013, 27, A4014004. [CrossRef]

260. Mohammed, A.A.; Mohammed, I.I.; Mohammed, S.A. Some properties of concrete with plastic aggregate derived from shredded PVC sheets. Constr. Build. Mater. 2019, 201, 232-245. [CrossRef]

261. Thorneycroft, J.; Orr, J.; Savoikar, P.; Ball, R. Performance of structural concrete with recycled plastic waste as a partial replacement for sand. Constr. Build. Mater. 2018, 161, 63-69. [CrossRef]

262. Saikia, N.; Brito, J.d. Waste polyethylene terephthalate as an aggregate in concrete. Mater. Res. 2013, 16, 341-350. [CrossRef]

263. Islam, M.J.; Meherier, M.S.; Islam, A.R. Effects of waste PET as coarse aggregate on the fresh and harden properties of concrete. Constr. Build. Mater. 2016, 125, 946-951. [CrossRef]

264. Manjunath, B.A. Partial replacement of E-plastic Waste as Coarse-aggregate in Concrete. Procedia Environ. Sci. 2016, 35, 731-739. [CrossRef]

265. Saikia, N.; de Brito, J. Mechanical properties and abrasion behaviour of concrete containing shredded PET bottle waste as a partial substitution of natural aggregate. Constr. Build. Mater. 2014, 52, 236-244. [CrossRef]

266. Mohammadinia, A.; Wong, Y.C.; Arulrajah, A.; Horpibulsuk, S. Strength evaluation of utilizing recycled plastic waste and recycled crushed glass in concrete footpaths. Constr. Build. Mater. 2019, 197, 489-496. [CrossRef]

267. Guendouz, M.; Debieb, F.; Boukendakdji, O.; Kadri, E.; Bentchikou, M.; Soualhi, H. Use of plastic waste in sand concrete. J. Mater. Env. Sci. 2016, 7, 382-389.

268. Hama, S.M.; Hilal, N.N. Fresh properties of self-compacting concrete with plastic waste as partial replacement of sand. Int. J. Sustain. Built Environ. 2017, 6, 299-308. [CrossRef]

269. Yang, S.; Yue, X.; Liu, X.; Tong, Y. Properties of self-compacting lightweight concrete containing recycled plastic particles. Constr. Build. Mater. 2015, 84, 444-453. [CrossRef]

270. Safi, B.; Saidi, M.; Aboutaleb, D.; Maallem, M. The use of plastic waste as fine aggregate in the self-compacting mortars: Effect on physical and mechanical properties. Constr. Build. Mater. 2013, 43, 436-442. [CrossRef]

271. Bulut, H.A.; Şahin, R. A study on mechanical properties of polymer concrete containing electronic plastic waste. Compos. Struct. 2017, 178, 50-62. [CrossRef]

272. Ge, Z.; Sun, R.; Zhang, K.; Gao, Z.; Li, P. Physical and mechanical properties of mortar using waste Polyethylene Terephthalate bottles. Constr. Build. Mater. 2013, 44, 81-86. [CrossRef]

273. da Silva, A.M.; de Brito, J.; Veiga, R. Incorporation of fine plastic aggregates in rendering mortars. Constr. Build. Mater. 2014, 71, 226-236. [CrossRef]

274. Kandasamy, R.; Murugesan, R. Fibre reinforced concrete using domestic waste plastics as fibres. Arpn J. Eng. Appl. Sci. 2011, 6, 75-82.

275. Foti, D. Preliminary analysis of concrete reinforced with waste bottles PET fibers. Constr. Build. Mater. 2011, 25, 1906-1915. [CrossRef]

276. Foti, D. Use of recycled waste pet bottles fibers for the reinforcement of concrete. Compos. Struct. 2013, 96, 396-404. [CrossRef]

277. Machovič, V.; Lapčák, L.; Borecka, L.; Lhotka, M.; Andertova, J.; Kopecký, L.; Mišková, L. Microstructure of interfacial transition zone between pet fibres and cement paste. Acta Geodyn. Et Geomater. 2013, 10, 121-127. [CrossRef]

278. Karthik, M.; Maruthachalam, D. Experimental study on shear behaviour of hybrid Fibre Reinforced Concrete beams. Ksce J. Civ. Eng. 2015, 19, 259-264. [CrossRef]

279. Baldenebro-Lopez, F.; Castorena-Gonzalez, J.; Velazquez-Dimas, J.; Ledezma-Sillas, J.; Gómez-Esparza, C.; Martinez-Sanchez, R.; Herrera-Ramirez, J. Influence of continuous plastic fibers reinforcement arrangement in concrete strengthened. Iosr J. Eng 2014, 4, 15-23. [CrossRef]

280. Taherkhani, H. An Investigation on the Properties of the Concrete Containing Waste PET Fibers. Int. J. Sci. Eng. Investig. 2014, 3, 37-43. 
281. Fraternali, F.; Spadea, S.; Berardi, V.P. Effects of recycled PET fibres on the mechanical properties and seawater curing of Portland cement-based concretes. Constr. Build. Mater. 2014, 61, 293-302. [CrossRef]

282. Spadea, S.; Farina, I.; Berardi, V.P.; Dentale, F.; Fraternali, F. Energy dissipation capacity of concretes reinforced with recycled PET fibers. Ing. Sismica 2014, 31, 61-70.

283. Koo, B.-M.; Kim, J.-H.J.; Kim, S.-B.; Mun, S. Material and structural performance evaluations of Hwangtoh admixtures and recycled PET fiber-added eco-friendly concrete for $\mathrm{CO}_{2}$ emission reduction. Materials 2014, 7, 5959-5981. [CrossRef]

284. Bhogayata, A.; Arora, N.; Nakum, A. Strength characteristics of concrete containing post consumer metalized plastic waste. Inter. J. Res. Eng. Tech. 2015, 4, 430-434.

285. Bhogayata, A.C.; Arora, N.K. Fresh and strength properties of concrete reinforced with metalized plastic waste fibers. Constr. Build. Mater. 2017, 146, 455-463. [CrossRef]

286. Bhogayata, A.C.; Arora, N.K. Impact strength, permeability and chemical resistance of concrete reinforced with metalized plastic waste fibers. Constr. Build. Mater. 2018, 161, 254-266. [CrossRef]

287. Bhogayata, A.C.; Arora, N.K. Workability, strength, and durability of concrete containing recycled plastic fibers and styrene-butadiene rubber latex. Constr. Build. Mater. 2018, 180, 382-395. [CrossRef]

288. Borg, R.P.; Baldacchino, O.; Ferrara, L. Early age performance and mechanical characteristics of recycled PET fibre reinforced concrete. Constr. Build. Mater. 2016, 108, 29-47. [CrossRef]

289. Pereira, E.L.; de Oliveira Junior, A.L.; Fineza, A.G. Optimization of mechanical properties in concrete reinforced with fibers from solid urban wastes (PET bottles) for the production of ecological concrete. Constr. Build. Mater. 2017, 149, 837-848. [CrossRef]

290. Mohammadhosseini, H.; Awal, A.A.; Yatim, J.B.M. The impact resistance and mechanical properties of concrete reinforced with waste polypropylene carpet fibres. Constr. Build. Mater. 2017, 143, 147-157. [CrossRef]

291. Mohammadhosseini, H.; Tahir, M.M.; Sam, A.R.M. The feasibility of improving impact resistance and strength properties of sustainable concrete composites by adding waste metalized plastic fibres. Constr. Build. Mater. 2018, 169, 223-236. [CrossRef]

292. Kurup, A.R.; Senthil Kumar, K. Effect of recycled PVC fibers from electronic waste and silica powder on shear strength of concrete. J. Hazard. ToxicRadioact. Waste 2017, 21, 06017001. [CrossRef]

293. Kurup, A.R.; Kumar, K.S. Novel fibrous concrete mixture made from recycled PVC fibers from electronic waste. J. Hazard. ToxicRadioact. Waste 2017, 21, 04016020. [CrossRef]

294. Karanth, S.S.; Ghorpade, V.G.; Rao, H.S. Shear and impact strength of waste plastic fibre reinforced concrete. Adv. Concr. Constr. 2017, 5, 173-182. [CrossRef]

295. Bui, N.K.; Satomi, T.; Takahashi, H. Recycling woven plastic sack waste and PET bottle waste as fiber in recycled aggregate concrete: An experimental study. Waste Manag. 2018, 78, 79-93. [CrossRef] [PubMed]

296. Khalid, F.; Irwan, J.; Ibrahim, M.W.; Othman, N.; Shahidan, S. Splitting tensile and pullout behavior of synthetic wastes as fiber-reinforced concrete. Constr. Build. Mater. 2018, 171, 54-64. [CrossRef]

297. Kiyanets, A. Concrete with recycled polyethylene terephthalate fiber. Mag. Civ. Eng. 2018, 84, 109-118.

298. Meza, A.; Siddique, S. Effect of aspect ratio and dosage on the flexural response of FRC with recycled fiber. Constr. Build. Mater. 2019, 213, 286-291. [CrossRef]

299. Hama, S.M. Improving mechanical properties of lightweight Porcelanite aggregate concrete using different waste material. Int. J. Sustain. Built Environ. 2017, 6, 81-90. [CrossRef]

300. Kandasamy, R.; Murugesan, R. Fiber Reinforced Self Compacting Concrete using domestic waste plastics as fibres. Jeas-J. Eng. Appl. Sci. 2012, 7, 405-410. [CrossRef]

301. Ghernouti, Y.; Rabehi, B.; Bouziani, T.; Ghezraoui, H.; Makhloufi, A. Fresh and hardened properties of self-compacting concrete containing plastic bag waste fibers (WFSCC). Constr. Build. Mater. 2015, 82, 89-100. [CrossRef]

302. Al-Hadithi, A.I.; Hilal, N.N. The possibility of enhancing some properties of self-compacting concrete by adding waste plastic fibers. J. Build. Eng. 2016, 8, 20-28. [CrossRef]

303. Yin, S.; Tuladhar, R.; Collister, T.; Combe, M.; Sivakugan, N.; Deng, Z. Post-cracking performance of recycled polypropylene fibre in concrete. Constr. Build. Mater. 2015, 101, 1069-1077. [CrossRef]

304. Khalid, F.; Irwan, J.; Ibrahim, M.W.; Othman, N.; Shahidan, S. Performance of plastic wastes in fiber-reinforced concrete beams. Constr. Build. Mater. 2018, 183, 451-464. [CrossRef] 
305. Pelisser, F.; Neto, A.B.d.S.S.; La Rovere, H.L.; de Andrade Pinto, R.C. Effect of the addition of synthetic fibers to concrete thin slabs on plastic shrinkage cracking. Constr. Build. Mater. 2010, 24, 2171-2176. [CrossRef]

306. Yin, S.; Tuladhar, R.; Riella, J.; Chung, D.; Collister, T.; Combe, M.; Sivakugan, N. Comparative evaluation of virgin and recycled polypropylene fibre reinforced concrete. Constr. Build. Mater. 2016, 114, 134-141. [CrossRef]

307. Smarzewski, P. Influence of basalt-polypropylene fibres on fracture properties of high performance concrete. Compos. Struct. 2019, 209, 23-33. [CrossRef]

308. de Oliveira, L.A.P.; Castro-Gomes, J.P. Physical and mechanical behaviour of recycled PET fibre reinforced mortar. Constr. Build. Mater. 2011, 25, 1712-1717. [CrossRef]

309. Al-Tulaian, B.; Al-Shannag, M.; Al-Hozaimy, A. Recycled plastic waste fibers for reinforcing Portland cement mortar. Constr. Build. Mater. 2016, 127, 102-110. [CrossRef]

310. Lin, X.; Yu, J.; Li, H.; Lam, J.Y.; Shih, K.; Sham, I.M.; Leung, C.K. Recycling polyethylene terephthalate wastes as short fibers in strain-hardening cementitious composites (SHCC). J. Hazard. Mater. 2018, 357, 40-52. [CrossRef]

311. Cheng, W.; Liu, G.; Chen, L. Pet fiber reinforced wet-mix shotcrete with walnut shell as replaced aggregate. Appl. Sci. 2017, 7, 345. [CrossRef]

312. Alghazali, H.H.; Aljazaeri, Z.R.; Myers, J.J. Effect of accelerated curing regimes on high volume Fly ash mixtures in precast manufacturing plants. Cem. Concr. Res. 2020, 131, 105913. [CrossRef]

313. Sunayana, S.; Barai, S.V. Flexural performance and tension-stiffening evaluation of reinforced concrete beam incorporating recycled aggregate and fly ash. Constr. Build. Mater. 2018, 174, 210-223. [CrossRef]

314. Sadati, S.; Arezoumandi, M.; Khayat, K.H.; Volz, J.S. Shear performance of reinforced concrete beams incorporating recycled concrete aggregate and high-volume fly ash. J. Clean. Prod. 2016, 115, 284-293. [CrossRef]

315. Ogawa, Y.; Bui, P.T.; Kawai, K.; Sato, R. Effects of porous ceramic roof tile waste aggregate on strength development and carbonation resistance of steam-cured fly ash concrete. Constr. Build. Mater. 2020, 236, 117462. [CrossRef]

316. Pati, P.; Sahu, S.K. Innovative utilization of fly ash in concrete tiles for sustainable construction. Mater. Today Proc. 2020. [CrossRef]

317. Krishnaraj, L.; Niranjan, R.; Kumar, G.P.; Kumar, R.S. Numerical and experimental investigation on mechanical and thermal behaviour of brick masonry: An efficient consumption of ultrafine fly ash. Constr. Build. Mater. 2020, 253, 119232. [CrossRef]

318. Tošić, N.; Marinković, S.; Pecić, N.; Ignjatović, I.; Dragaš, J. Long-term behaviour of reinforced beams made with natural or recycled aggregate concrete and high-volume fly ash concrete. Constr. Build. Mater. 2018, 176, 344-358. [CrossRef]

319. Fuzail Hashmi, A.; Shariq, M.; Baqi, A. Flexural performance of high volume fly ash reinforced concrete beams and slabs. Structures 2020, 25, 868-880. [CrossRef]

320. Šejnoha, M.; Brouček, M.; Novotná, E.; Keršner, Z.; Lehký, D.; Frantík, P. Fracture properties of cement and alkali activated fly ash based concrete with application to segmental tunnel lining. Adv. Eng. Softw. 2013, 62-63, 61-71. [CrossRef]

321. Swathi, V.; Asadi, S.S.; Poluraju, P. An integrated methodology for structural performance of high-volume fly ash concrete beams using hybrid fibers. Mater. Today Proc. 2020, 27, 1630-1635. [CrossRef]

322. Gao, Y.; He, B.; Li, Y.; Tang, J.; Qu, L. Effects of nano-particles on improvement in wear resistance and drying shrinkage of road fly ash concrete. Constr. Build. Mater. 2017, 151, 228-235. [CrossRef]

323. Wang, L.; Yang, H.Q.; Zhou, S.H.; Chen, E.; Tang, S.W. Mechanical properties, long-term hydration heat, shinkage behavior and crack resistance of dam concrete designed with low heat Portland (LHP) cement and fly ash. Constr. Build. Mater. 2018, 187, 1073-1091. [CrossRef]

324. Woszuk, A.; Bandura, L.; Franus, W. Fly ash as low cost and environmentally friendly filler and its effect on the properties of mix asphalt. J. Clean. Prod. 2019, 235, 493-502. [CrossRef]

325. Choi, M.J.; Kim, Y.J.; Kim, H.J.; Lee, J.J. Performance evaluation of the use of tire-derived fuel fly ash as mineral filler in hot mix asphalt concrete. J. Traffic Transp. Eng. (Engl. Ed.) 2020, 7, 249-258. [CrossRef]

326. She, W.; Du, Y.; Zhao, G.; Feng, P.; Zhang, Y.; Cao, X. Influence of coarse fly ash on the performance of foam concrete and its application in high-speed railway roadbeds. Constr. Build. Mater. 2018, 170, 153-166. [CrossRef] 
327. Lam, M.N.-T.; Le, D.-H.; Jaritngam, S. Compressive strength and durability properties of roller-compacted concrete pavement containing electric arc furnace slag aggregate and fly ash. Constr. Build. Mater. 2018, 191, 912-922. [CrossRef]

328. Chindaprasirt, P.; Rattanasak, U. Fabrication of self-cleaning fly ash/polytetrafluoroethylene material for cement mortar spray-coating. J. Clean. Prod. 2020, 264, 121748. [CrossRef]

329. Mohammed, B.S.; Adamu, M.; Liew, M.S. Evaluating the effect of crumb rubber and nano silica on the properties of high volume fly ash roller compacted concrete pavement using non-destructive techniques. Case Stud. Constr. Mater. 2018, 8, 380-391. [CrossRef]

330. Apithanyasai, S.; Supakata, N.; Papong, S. The potential of industrial waste: Using foundry sand with fly ash and electric arc furnace slag for geopolymer brick production. Heliyon 2020, 6, e03697. [CrossRef]

331. Zanini, M.A. Structural reliability of bridges realized with reinforced concretes containing electric arc furnace slag aggregates. Eng. Struct. 2019, 188, 305-319. [CrossRef]

332. Arabani, M.; Azarhoosh, A.R. The effect of recycled concrete aggregate and steel slag on the dynamic properties of asphalt mixtures. Constr. Build. Mater. 2012, 35, 1-7. [CrossRef]

333. Jiao, Z.; Wang, Y.; Zheng, W.; Huang, W.; Zhao, Y. Bond properties of alkali-activated slag concrete hollow block masonry with different mortar strength grades. Constr. Build. Mater. 2019, 216, 149-165. [CrossRef]

334. Gopalakrishnan, R.; Nithiyanantham, S. Microstructural, mechanical, and electrical properties of copper slag admixtured cement mortar. J. Build. Eng. 2020, 31. [CrossRef]

335. Shin, H.-O.; Yang, J.-M.; Yoon, Y.-S.; Mitchell, D. Mix design of concrete for prestressed concrete sleepers using blast furnace slag and steel fibers. Cem. Concr. Compos. 2016, 74, 39-53. [CrossRef]

336. Yang, J.-M.; Shin, H.-O.; Yoon, Y.-S.; Mitchell, D. Benefits of blast furnace slag and steel fibers on the static and fatigue performance of prestressed concrete sleepers. Eng. Struct. 2017, 134, 317-333. [CrossRef]

337. Albitar, M.; Mohamed Ali, M.S.; Visintin, P. Experimental study on fly ash and lead smelter slag-based geopolymer concrete columns. Constr. Build. Mater. 2017, 141, 104-112. [CrossRef]

338. Salvador, R.P.; Rambo, D.A.S.; Bueno, R.M.; Silva, K.T.; Figueiredo, A.D.d. On the use of blast-furnace slag in sprayed concrete applications. Constr. Build. Mater. 2019, 218, 543-555. [CrossRef]

339. Fuente-Alonso, J.A.; Ortega-López, V.; Skaf, M.; Aragón, Á.; San-José, J.T. Performance of fiber-reinforced EAF slag concrete for use in pavements. Constr. Build. Mater. 2017, 149, 629-638. [CrossRef]

340. Lam, M.N.-T.; Jaritngam, S.; Le, D.-H. Roller-compacted concrete pavement made of Electric Arc Furnace slag aggregate: Mix design and mechanical properties. Constr. Build. Mater. 2017, 154, 482-495. [CrossRef]

341. Gupta, T.; Sachdeva, S.N. Laboratory investigation and modeling of concrete pavements containing AOD steel slag. Cem. Concr. Res. 2019, 124, 105808. [CrossRef]

342. Liu, J.; Yu, B.; Wang, Q. Application of steel slag in cement treated aggregate base course. J. Clean. Prod. 2020, 269, 121733. [CrossRef]

343. Yuan, F.; Shen, L.-Y.; Li, Q.-M. Emergy analysis of the recycling options for construction and demolition waste. Waste Manag. 2011, 31, 2503-2511. [CrossRef]

344. Elgizawy, S.M.; El-Haggar, S.M.; Nassar, K. Approaching sustainability of construction and demolition waste using zero waste concept. Low Carbon Econ. 2016, 7, 1-11. [CrossRef]

345. Del Río Merino, M.; Izquierdo Gracia, P.; Weis Azevedo, I.S. Sustainable construction: Construction and demolition waste reconsidered. Waste Manag. Res. 2010, 28, 118-129. [CrossRef] [PubMed]

346. Pacheco-Torgal, F.; Ding, Y. Handbook of Recycled Concrete and Demolition Waste; Elsevier: Amsterdam, The Netherlands, 2013.

347. Kumbhar, S.; Gupta, A.; Desai, D. Recycling and reuse of construction and demolition waste for sustainable development. Oida Int. J. Sustain. Dev. 2013, 6, 83-92.

348. Akhtar, A.; Sarmah, A.K.; Akhtar, A.; Sarmah, A.K. Novel biochar-concrete composites: Manufacturing, characterization and evaluation of the mechanical properties. Sci. Total Environ. 2018, 616, 408-416. [CrossRef] [PubMed]

349. Martín-Morales, M.; Zamorano, M.; Ruiz-Moyano, A.; Valverde-Espinosa, I. Characterization of recycled aggregates construction and demolition waste for concrete production following the Spanish Structural Concrete Code EHE-08. Constr. Build. Mater. 2011, 25, 742-748. [CrossRef]

350. De Brito, J.; Agrela, F. New Trends in Eco-Efficient and Recycled Concrete; Woodhead Publishing: Oxford, $\mathrm{UK}, 2018$. 
351. Senaratne, S.; Lambrousis, G.; Mirza, O.; Tam, V.W.Y.; Kang, W.-H. Recycled Concrete in Structural Applications for Sustainable Construction Practices in Australia. Procedia Eng. 2017, 180, 751-758. [CrossRef]

352. Favaretto, P.; Hidalgo, G.E.N.; Sampaio, C.H.; Silva, R.D.A.; Lermen, R.T. Characterization and use of construction and demolition waste from south of Brazil in the production of foamed concrete blocks. Appl. Sci. 2017, 7, 1090. [CrossRef]

353. Wang, X.; Yu, R.; Shui, Z.; Song, Q.; Liu, Z.; Bao, M.; Liu, Z.; Wu, S. Optimized treatment of recycled construction and demolition waste in developing sustainable ultra-high performance concrete. J. Clean. Prod. 2019, 221, 805-816. [CrossRef]

354. Akhtar, A.; Sarmah, A.K. Construction and demolition waste generation and properties of recycled aggregate concrete: A global perspective. J. Clean. Prod. 2018, 186, 262-281. [CrossRef]

355. Rajhans, P.; Panda, S.K.; Nayak, S. Sustainability on durability of self compacting concrete from C\&D waste by improving porosity and hydrated compounds: A microstructural investigation. Constr. Build. Mater. 2018, 174, 559-575.

356. Di Maria, A.; Eyckmans, J.; Van Acker, K. Downcycling versus recycling of construction and demolition waste: Combining LCA and LCC to support sustainable policy making. Waste Manag. 2018, 75, 3-21. [CrossRef] [PubMed]

357. Ding, T.; Xiao, J. Estimation of building-related construction and demolition waste in Shanghai. Waste Manag. 2014, 34, 2327-2334. [CrossRef] [PubMed]

358. Xiao, J.; Ma, Z.; Sui, T.; Akbarnezhad, A.; Duan, Z. Mechanical properties of concrete mixed with recycled powder produced from construction and demolition waste. J. Clean. Prod. 2018, 188, 720-731. [CrossRef]

359. Zhang, J.; Gu, F.; Zhang, Y. Use of building-related construction and demolition wastes in highway embankment: Laboratory and field evaluations. J. Clean. Prod. 2019, 230, 1051-1060. [CrossRef]

360. Silva, R.V.; de Brito, J.; Dhir, R.K. Use of recycled aggregates arising from construction and demolition waste in new construction applications. J. Clean. Prod. 2019, 236, 117629. [CrossRef]

361. Tam, V.W.Y.; Soomro, M.; Evangelista, A.C.J. A review of recycled aggregate in concrete applications (2000-2017). Constr. Build. Mater. 2018, 172, 272-292. [CrossRef]

362. Braga, A.M.; Silvestre, J.D.; de Brito, J. Compared environmental and economic impact from cradle to gate of concrete with natural and recycled coarse aggregates. J. Clean. Prod. 2017, 162, 529-543. [CrossRef]

363. Silvestre, J.D.; de Brito, J.; Pinheiro, M.D. From the new European Standards to an environmental, energy and economic assessment of building assemblies from cradle-to-cradle (3E-C2C). Energy Build. 2013, 64, 199-208. [CrossRef]

364. Jin, R.; Li, B.; Zhou, T.; Wanatowski, D.; Piroozfar, P. An empirical study of perceptions towards construction and demolition waste recycling and reuse in China. Resour. Conserv. Recycl. 2017, 126, 86-98. [CrossRef]

365. Wang, J.; Li, Z.; Tam, V.W. Identifying best design strategies for construction waste minimization. J. Clean. Prod. 2015, 92, 237-247. [CrossRef]

366. Singh, M.; Choudhary, K.; Srivastava, A.; Sangwan, K.S.; Bhunia, D. A study on environmental and economic impacts of using waste marble powder in concrete. J. Build. Eng. 2017, 13, 87-95. [CrossRef]

367. Behera, M.; Bhattacharyya, S.; Minocha, A.; Deoliya, R.; Maiti, S. Recycled aggregate from C\&D waste \& its use in concrete-A breakthrough towards sustainability in construction sector: A review. Constr. Build. Mater. 2014, 68, 501-516.

368. Cabral, A.E.B.; Schalch, V.; Dal Molin, D.C.C.; Ribeiro, J.L.D. Mechanical properties modeling of recycled aggregate concrete. Constr. Build. Mater. 2010, 24, 421-430. [CrossRef]

369. Knoeri, C.; Sanyé-Mengual, E.; Althaus, H.-J. Comparative LCA of recycled and conventional concrete for structural applications. Int. J. Life Cycle Assess. 2013, 18, 909-918. [CrossRef]

370. Bravo, M.; De Brito, J.; Pontes, J.; Evangelista, L. Mechanical performance of concrete made with aggregates from construction and demolition waste recycling plants. J. Clean. Prod. 2015, 99, 59-74. [CrossRef]

371. Dantas, A.T.A.; Leite, M.B.; de Jesus Nagahama, K. Prediction of compressive strength of concrete containing construction and demolition waste using artificial neural networks. Constr. Build. Mater. 2013, 38, 717-722. [CrossRef]

372. Sabai, M.; Cox, M.; Mato, R.; Egmond, E.; Lichtenberg, J. Concrete block production from construction and demolition waste in Tanzania. Resour. Conserv. Recycl. 2013, 72, 9-19. [CrossRef]

373. Dadsetan, S.; Siad, H.; Lachemi, M.; Sahmaran, M. Construction and demolition waste in geopolymer concrete technology: A review. Mag. Concr. Res. 2019, 71, 1232-1252. [CrossRef] 
374. Sandanayake, M.; Zhang, G.; Setunge, S. Environmental emissions at foundation construction stage of buildings-Two case studies. Build. Environ. 2016, 95, 189-198. [CrossRef]

375. Mao, C.; Shen, Q.; Shen, L.; Tang, L. Comparative study of greenhouse gas emissions between off-site prefabrication and conventional construction methods: Two case studies of residential projects. Energy Build. 2013, 66, 165-176. [CrossRef]

376. Hong, J.; Shen, G.Q.; Feng, Y.; Lau, W.S.-T.; Mao, C. Uncertainty analysis for measuring greenhouse gas emissions in the building construction phase: A case study in China. J. Clean. Prod. 2016, 129, 183-195. [CrossRef]

377. Gunasekara, C.; Law, D.W.; Setunge, S.; Sanjayan, J.G. Zeta potential, gel formation and compressive strength of low calcium fly ash geopolymers. Constr. Build. Mater. 2015, 95, 592-599. [CrossRef]

378. Gunasekara, C.; Law, D.W.; Setunge, S. Long term permeation properties of different fly ash geopolymer concretes. Constr. Build. Mater. 2016, 124, 352-362. [CrossRef]

379. Gunasekara, C.; Setunge, S.; Law, D.W. Long-term mechanical properties of different fly ash geopolymers. Aci Struct. J. 2017, 114, 743-752. [CrossRef]

380. Sandanayake, M.; Luo, W.; Zhang, G. Direct and indirect impact assessment in off-site construction-A case study in China. Sustain. Cities Soc. 2019, 48, 101520. [CrossRef]

381. Sutcu, M.; Alptekin, H.; Erdogmus, E.; Er, Y.; Gencel, O. Characteristics of fired clay bricks with waste marble powder addition as building materials. Constr. Build. Mater. 2015, 82, 1-8. [CrossRef]

382. Saberian, M.; Shi, L.; Sidiq, A.; Li, J.; Setunge, S.; Li, C.-Q. Recycled concrete aggregate mixed with crumb rubber under elevated temperature. Constr. Build. Mater. 2019, 222, 119-129. [CrossRef]

383. Australia, G.B.C. Green Star Overview; Green Building Council of Australia: Sydney, Australia, 2015. Available online: www.gbca.org.au/green-star/green-star-overview/ (accessed on 15 August 2020).

384. Wu, P.; Mao, C.; Wang, J.; Song, Y.; Wang, X. A decade review of the credits obtained by LEED v2. 2 certified green building projects. Build. Environ. 2016, 102, 167-178. [CrossRef]

385. Chen, X.; Yang, H.; Zhang, W. A Proposed New Weighting System for Passive Design Approach in BEAM Plus. Energy Procedia 2017, 105, 2113-2118. [CrossRef]

386. Illankoon, I.C.S.; Tam, V.W.; Le, K.N.; Shen, L. Key credit criteria among international green building rating tools. J. Clean. Prod. 2017, 164, 209-220. [CrossRef]

387. Illankoon, I.M.C.S.; Tam, V.W.Y.; Le, K.N. Environmental, Economic, and Social Parameters in International Green Building Rating Tools. J. Prof. Issues Eng. Educ. Pract. 2017, 143, 05016010. [CrossRef]

Publisher's Note: MDPI stays neutral with regard to jurisdictional claims in published maps and institutional affiliations.

(C) 2020 by the authors. Licensee MDPI, Basel, Switzerland. This article is an open access article distributed under the terms and conditions of the Creative Commons Attribution (CC BY) license (http://creativecommons.org/licenses/by/4.0/). 